\title{
Reconciliation Here on Earth
}

James Tully

In Michael Asch, John Borrows \& James Tully, eds., Reconciliation and Resurgence

(Forthcoming, 2018)

\section{Overview}

I would like to discuss two interconnected projects of reconciliation. The first is the reconciliation of indigenous and non-indigenous people (natives and newcomers) with each other in all our diversity. The second is the reconciliation of indigenous and non-indigenous people (human beings) with the living earth: that is, reconciliation with more-than-human living beings (plants, animals, ecosystems and the living earth as a whole). I will not discuss formal reconciliation procedures carried on by governments, courts and commissions. Rather I focus on more basic, informal and transformative practices of reconciliation and the shared responsibilities we all have to engage in these two projects of reconciliation. ${ }^{1}$ This first section sets out the general argument and the following three sections explore aspects of it.

\section{I.1 Two connected projects of reconciliation}

My suggestion is that these two projects of reconciliation have to be brought into being and carried on together if they are to be successful. Our relationships with each other and our relationships with the living earth are far too interdependent and entangled to treat their reconciliation separately, as if they were independent. They have been woven together since first contact in countless ways; sometimes in good ways, but also in multiple forms of intergenerational social and ecological suffering; understanding and misunderstanding; working together and domination, dispossession, colonization, cultural genocide, subordination, impoverishment, residential school, and starvation; and through treaty negotiations, violations, blockades, armed and unarmed conflicts, constitutional change, court cases, modern treaties, successful and failed consultations, and the complex web of relationships in every area of contemporary life that has evolved over the last thirty years. 
Just think for a moment of trying to separate these two types of reconciliation: with each other in our diversity and the living earth in its diversity. ${ }^{2}$ If we try to reconcile indigenous and non-indigenous people with each other without reconciling our way of life with the living earth, we will fail because the unsustainable and crisis-ridden relationship between indigenous and nonindigenous people that we are trying to re-conciliate has its deepest roots in the unsustainable and crisis-ridden relationship between human beings and the living earth. ${ }^{3}$ To put it more strongly, as long as our unsustainable relationship to the living earth is not challenged, it will constantly undermine and subvert even the most well-meaning, free-standing efforts to reconcile the unsustainable relationship between indigenous and non-indigenous peoples through modern treaties and consultations, as we have seen over the last thirty years. These two crises form an interconnected 'dual crisis', as I call it.

If, conversely, we try to reconcile the unsustainable relationship with the living earth without addressing the unsustainable relationship with indigenous and non-indigenous people, we will fail to discern and realize a good, sustainable relationship because such a relationship is discovered and learned through practice. We come to see the contours of this sustainable way of life here on earth through enacting it. Indigenous people have been living in sustainable ways with the living earth on Turtle Island for 10,000-14,000 years. Many Indigenous peoples have preserved their living traditional ecological knowledges of sustainable practices in the eco-regions and traditions in which this practical knowledge has been acquired by trial and error and passed on each generation. Indigenous peoples and their practical knowledge systems have co-evolved with the ecosystems in which they have co-inhabited, learned from, shaped and been shaped. These are place-based traditions of embedded practical knowledge required to learn how to make the transition to sustainable relationships with the ecosystems of the living earth. ${ }^{4}$ Bypassing indigenous peoples and indigenous sciences would be epistemic injustice and the continuation of the social injustice of dispossession and colonization, and the consequence would be ecological injustice. $^{5}$

Of course we need to draw on Western natural and human sciences as well. However, several of these sciences developed along with the underlying unsustainable relationship with the living earth during the last four hundred years of European global imperialism. As a result, they presuppose and overlook the unsustainable, extraction relationship to the living earth that is the cause of the ecological crisis, including climate change, and its social and economic consequences. 
Many of their responses to the ecological crisis thus tend to reproduce, rather than question, this underlying feature, and thus amplify its destructive effects. Moreover, they often take a dismissive stance to indigenous knowledges and lifeways as primitive, superstitious, soon to die off, lower or less-developed relative to the superior knowledge and processes of civilization, modernization and globalization spread around the globe by Western peoples. And these two imperious attitudes to the living earth and indigenous peoples are closely related historically and conceptually. ${ }^{6}$

Although these attitudes persist in several quarters, fortunately for life on earth, a very different way of thinking about the living earth and our interdependent relationships within and with it has developed and gained support in the life and earth systems sciences over the last fifty years. ${ }^{7}$ During the same period, a different way of recognizing and relating with indigenous and non-indigenous people and peoples, as different yet equal and interdependent, has developed slowly in the human sciences and in practice. ${ }^{8}$ Building on this double revolution, groups such as the Indigenous Peoples Working Group on Climate Change argue that indigenous and nonindigenous people are now able to join hands and work together, sharing indigenous and western knowledges on equal footing, to get at the roots of the dual crisis and work out reconciliatory and sustainable futures together. ${ }^{9}$ I agree. This double revolution and convergence can provide the common ground for a profound, transformative reconciliation with each other and the living earth if it is understood and enacted slowly and carefully in mutually respectful, responsible and diversity aware ways.

\section{I.2 The educational gift-reciprocity cycle of reconciliation practices}

Once we begin to see the two relationships with each other and the living earth as systemically interdependent (as the result of the two epistemic revolutions of I.1), we can also see the reciprocal educational relationship between the two types of reconciliation. First, we learn how to reconcile differences between indigenous and non-indigenous people and live together, not only by learning the arts of conciliation, or peacemaking, but also the arts and sciences of learning to live sustainably with the living earth. For, there are important lessons from a sustainable humanwith-nature relationship for a sustainable human-with-human relationship because all humanwith-human relationships (social systems) are embedded in and dependent on human-with-nature relationships. Second, there are even more fundamental lessons to be learned from the ways that non-human living systems have sustained themselves and co-evolved over 3.8 billion years for 
working up sustainable human-with-nature relationships; and then from there to indigenous-withnon-indigenous relationships.

The ways that 'life sustains life' in the webs of life that comprise the ecosphere is our primary teacher in both cases of reconciliation. Indeed, this multidisciplinary education - of the ecological and life sciences, the social sciences and humanities, and the indigenous arts and sciences - is the most important pedagogical task of the twenty-first century if we are to have a sustainable shared future. ${ }^{10}$ It is our task as educators and students working together to bring about this reunion of the natural and human sciences and traditional ecological knowledge and wisdom. This is how one of the pioneers, Fritz Capra, puts the educational challenge: ${ }^{11}$

The key to an operational definition of ecological sustainability is the realization that we do not need to invent sustainable human communities from scratch but can model them after nature's ecosystems, which are sustainable communities of plants, animals and microorganisms. Since the outstanding characteristic of the Earth household is its inherent ability to sustain life, a sustainable human community is one designed in such a manner that its ways of life, businesses, economies, federations, physical structures, and technologies do not interfere with nature's inherent ability to sustain life. Sustainable communities and networks evolve their patterns of living over time in continual interaction with other living systems, both human and non-human.

However, this great project of our time cannot be done justly or intelligently without the ongoing consent and co-operation of indigenous people who have co-evolved with and learned from their ecosystems: the very ecosystems from which non-indigenous people now want to learn how life sustains life in order to save themselves from the Anthropogenic crisis they have created by ignoring both teachers. ${ }^{12}$

This cooperative, interactive and dynamic view of eco-social education is not new. First, ever since settlers arrived on Turtle Island indigenous peoples have said that the proper way to reconcile our differences and live sustainably together is to enter into conciliatory treaty negotiations, and these will bring into being peaceful and friendly relationships among us. These conciliatory negotiations are never perfect. They are activities in which the participants learn by trial and error how to conciliate each other. Future generations always have to return to treaty talks and renew them as new circumstances arise. ${ }^{13}$ 
Second, indigenous people also have insisted that sustainable co-existence by means of treaty negotiations and the peaceful and friendly relationships they create is not a social system they invented ex nihilo. Rather, they say that they learn lessons of how to conciliate and live with the settlers from their interactions and negotiations with their other living relatives and kin: that is, sustainable relationships with plants, animals, streams, rivers, mountains, seasons, ecosystems, and mother earth as a whole. They often speak of these relationships with their more-than-human relatives as treaty relationships. Third, even these pedagogical relationships are not the primary ground of their knowledge of how to live in conciliatory and sustainable ways. They say they have learned how to live sustainably with the living earth by learning from how the webs of non-human forms of life live together symbiotically; that is, how life sustains life. This is the basic lifeworld in which the other two sustainable ways of life emerge and in which they have their interdependent being. For example, John Borrows explains the Anishinaabe concept of education (akinoomaage) in the following way: ${ }^{14}$

The word akinoomaage is composed by combining two roots: aki and noomage. Aki means 'earth'; noomage means 'to point towards and take direction from. Thus, philosophical inquiry within Anishinaabe can literally refer to the lessons we learn from understanding the earth.

But this is not all. Indigenous people have an important way of trying to bring settlers around to see that the conciliatory and sustainability skills one is supposed to learn in treaty negotiations are derived from the two broader types of living relationships in which treaty negotiations take place. They exchange gifts. The reason for this is that the cyclical exchange of gifts is the exemplar and reminder of the ways life sustains life symbiotically: that is, by giftreciprocity networks and cycles. ${ }^{15}$

Every second of the day the living earth gives countless gifts of goods and services needed to sustain all the interdependent forms of life, beginning with the air you are breathing here and now. Each interdependent form of life not only sustains itself, but also, in so doing, produces goods and services that help to sustain others; and vice versa. Accordingly, the way life sustains life by reproducing the conditions of life is portrayed as the mutual exchange of gifts among interdependent partners.

Gift exchange at treaty talks reminds the partners that they too should see themselves as both embedded in these cyclical gift-reciprocity relationships and bringing into being new ones in 
the negotiations. Just as the living earth consists of gift-reciprocity relationships that sustain the living members, so humans should relate to the living earth and each other in their eco-social relationships in the same general way. That is: a gift is given; the recipient expresses the emotion of gratitude and the giver perceives this. The emotion of gratitude moves the recipient to reciprocate by giving a gift to the giver and/or to others in reciprocity. In so doing, participants bring into being and continue gift-gratitude-reciprocity networks and cycles that co-sustain all participants: treaty and social networks that mimic self-sustaining ecological networks. If, conversely, they fail to reciprocate with mother earth or their treaty partners, take and exploit gifts with ingratitude and greed, they break the cycles that sustain life in both cases, destroy the cyclical networks that are the conditions of life for their neighbours and themselves, and eventually destroy themselves. ${ }^{16}$

Accordingly, the exchange of gifts before and after treaty talks reminds the participants that they have shared responsibilities to connect or 'reconnect' with the gift-gratitude-reciprocity cycles that sustain all forms of life. As Taiaiake Alfred reminds us, the Haudenosaunee acknowledge the responsibilities humans have to live in accordance with these life-sustaining relationships before entering into treaty negotiations: ${ }^{17}$

We gather together and see that the cycle of life continues. As human beings we have been given the responsibility to live in balance and harmony with each other and with all creation. So now, we bring our minds together as one as we give greetings and thanks to each other as People. Now our minds are one. We are thankful for our mother, mother earth, for she gives us all that we need for life. She sustains and supports us as our feet move upon her. We are joyful in knowing that she continues to care for us as she has from the beginning of time. To our Mother, we send greetings and thanks. Now our minds are one.

The living networks and cycles of gift-gratitude-reciprocity are the model not only for educational and treaty relationships, but for social and economic relationships more generally. On the Northwest coast, for example, the central term for systems of law, governance and civic education is 'potlatch'. Potlatch derives from the Nootka term 'pa-chitle', which means to give and to give in reciprocity. ${ }^{18}$ Nancy Turner refers to this gift-reciprocity understanding of the networks and cycles that sustain life a 'kincentric' worldview. ${ }^{19}$

\section{I.3 The independence view}


Accordingly, these views of interdependency and shared responsibilities are not new or unusual. Quite the contrary. The new and unusual view is the one that has become predominant in the Anthropocene Age: of the independence of human relationships from ecological relationships and from each other, and so the separation of the two activities of reconciliation. ${ }^{20}$

It is astonishing that anyone ever thought that indigenous and non-indigenous peoples could reconcile themselves without simultaneously reconciling our relationship with the living earth; as if they were independent causally and educationally. It shows how deeply we have been shaped and formed by an alienated relationship to the living earth and each other in the modern period. It is as if we are negotiating treaty relationships with one another and not realizing that we are also walking on this living earth, breathing its clean air, and receiving all the gifts it provides to keep us alive. As deep ecologists say, we independent and autonomous moderns overlook our interdependent 'ecological footprint' and 'ecological self'. ${ }^{21}$

I am not referring to the relationships that are standardly negotiated in formal reconciliation processes: sovereignty, jurisdiction, land claims, and so on. These are not overlooked - quite the opposite. I am referring to the primary underlying relationship of Homo sapiens with the living earth that is articulated in terms of gift-reciprocity relationships and cycles by indigenous people. This is a basic mode of being-in-the-lifeworld with other living beings; a reciprocal and interactive relationship of ongoing sensuous attunement, disturbance and re-attunement by means of our prereflective, embodied and reflective senses, perception and cognition. ${ }^{22}$ Following Aldo Leopold I call this primary relationship an 'ethical' relationship. Our shared responsibilities to reconcile unsustainable relationships derive from, and are the expression of, this basic ethical relationship. These are shared responsibilities we have as 'plain members and citizens' of the commonwealth of biotic communities of all forms of life on earth. ${ }^{23}$

The irresponsible attitude of overlooking this ethical relationship of interdependency has come along with the rise of the underlying unsustainable relationship to the living earth over the last four hundred years. From within this way of life, it appears as if we are independent of the living earth and of each other. Not only are the two projects of reconciliation seen as separate. We have no shared responsibilities to address them because we do not see ourselves as interdependent citizens of a commonwealth of all forms of life. This ground of being-with is overlooked. As I argue below, this alienated view of our social and ecological relationships and responsibilities is 
self-defeating; unable to see clearly or address effectively the ecological crisis or the indigenoussettler crisis.

\section{I.4 Conciliation, crisis, reconciliation cycles}

If the two projects of reconciliation are interdependent systemically and educationally, then what is the appropriate form of reconciliation to carry them out successfully? This is the question I wish to explore. I will set out five defining criteria of the transformative concept of reconciliation (reconciliation-with) I use. It is not to be confused with the predominant concept of reconciliation (reconciliation-to) in use today. This less-demanding concept of reconciliation (reconciliation-to) rests on the assumption that processes of reconciliation of indigenous and non-indigenous people are independent of their current unsustainable relationship with the living earth. In German there are two separate terms: Versohnung (transformative reconciliation-with) and Vertragen (reconciliation-to some independent, background system of knowledge and power). In English, there is only one word for both and this has caused immense confusion. ${ }^{24}$

Nuu-chah-nulth people have an expression for reconciliation-with and within the complex webs of interdependency that sustain life. As Umeek (Richard Atleo Senior) explains, when things are out of balance and in a crisis situation, such as the global crisis, and require reconciliation, they standardly begin by reminding themselves that everything is connected with and dependent on everything else. The Nuu-chah-nulth phrase is 'Heshook-ish Tsawalk'. ${ }^{25}$ Being is 'being-with' (Mitsein). Once we perceive ourselves to be always already in life-sustaining relationships of mutual dependence and assistance, the appropriate concept of both conciliation and reconciliation then appears to be: reconciliation-with all living beings, rather than reconciliation-to a presumptively unproblematic relationship to the living earth; reconciliation as ongoing, shared practices with all our relatives, rather than reconciliation as segmented processes oriented to independence; and the way of reconciliation as the enactment of the conciliatory and sustainable mode of being we are trying to bring about, rather than reconciliation as instrumental means different from the ends. That is, transformative reconciliation is the enactment and continuation of the primary ethical relationship mentioned above.

For our purposes, there are five main features of reconciliation as reconciliation-with. First, it is a form of activity that comes on the scene in response to a crisis in the sustainable and conciliatory way of life of the people involved; whether this crisis irrupts in family relationships, 
relationships among communities and peoples, or among humans and non-human forms of life. The relationships among them become crisis-ridden and unsustainable. In the conciliatory phase, the members work and live together in mutually sustainable ways among themselves and with all other interdependent social and ecological communities on which they co-depend. When disagreements, problems and conflicts arise, as they always do, they normally can conciliate them by the means available to them within their way of life; or within ways of life if it is a dispute with neighbouring communities, human or non-human.

A crisis of sustainability and conciliation irrupts when conciliation fails for some reason. ${ }^{26}$ The people involved become ungrateful, greedy, distrustful, conflictual and aggressive rather than peaceful and conciliatory; alienated from each other and estranged from the living earth. If they continue to reproduce these behaviours they will destroy themselves and interrelated forms of life (their relatives or neighbours). When they try to respond to the crisis, the result is often to amplify rather than attenuate the destructive effects of their crisis-ridden way of life. Their way of life becomes unsustainable and self-destructive (vicious) rather than self-sustaining and mutually beneficial (virtuous). From within the crisis phase, their relationships appear to be irreconcilable. This is the crises situation we are in today with respect to relations between indigenous and nonindigenous peoples and the living earth. ${ }^{27}$

The crisis of indigenous peoples is beyond reasonable doubt. It has been exhaustively reported, studied and documented from the 1960s, through the Royal Commission on Aboriginal People in the 1990s, the attempts to address it in the 2000s, and to The Truth and Reconciliation Commission and murdered and missing Aboriginal Women today. ${ }^{28}$ As John Borrows puts it: ${ }^{29}$

Aboriginal peoples' lives are drastically shorter than other Canadians and marked by more suffering as measured by considerably higher rates of poverty, injury, and incarceration, and significantly lower levels of education, income and health. This did not occur in an instant; we have long passed the 'tipping point' in the relationship between Aboriginal peoples and others. We are in crisis mode, and there is no politically-driven prospect of salvaging the relationship; it is already broken and lies in ruins all around us.

The ecological crisis of the very conditions of life on earth is also beyond reasonable doubt. Since the early reports on climate change, global warming, pollution, and the limits to growth in the 1970s to endless studies and reports of the leadings earth scientists in the world and the Intergovernmental Panel on Climate Change, we have known that our dominant way of life is 
overshooting the carrying capacity of the earth and destroying the conditions that sustain life. Climate change, non-renewable and renewable resource depletion, species and ecosystems extinction, the melting of glaciers and the polar ice cap, the acidification of the oceans and desertification of former agricultural and forest lands are not only past the tipping point to unsustainable warming and a possible sixth mass extinction. They are already bringing about horrendous social effects: mass starvation and migration, social divisions and a planet of slums and gated communities, wars over resources and water, and failed states. The ruthless race among states and corporations for the resources that are left is accelerating climate change and other factors in a vicious, cascading and runaway spiral. The intensified race to control the world's remaining resources has increased intervention and exploitation of the territories and resources of indigenous peoples, drawing them into the spiraling social and economic consequences. ${ }^{30}$ The interdependent relationships, systems and cycles that sustain life on earth are 'on the edge'. 31

Second, reconciliation is a mode of ethical practice with others here and now; in the unsustainable and crisis-ridden relationships indigenous and non-indigenous people inhabit. Reconciliation consists in the exercise of our shared responsibilities to care for ourselves and for all the interdependent others on whom our own well-being depends. That is, the practice of reconciliation is simply the attempt to bring into being or to regenerate, to enact, and carry on the basic ethical relationship of mutual responsiveness, care, conciliation and sustainability with all forms of life that is being overlooked and destroyed by the dominant self-destructive relationships that are causing the crisis.

The extreme difficulty of reconciliation in this profound sense is that we are ourselves located within the self-destructive relationships: subject to them and their legitimating ideologies, governed and swept along by them in our everyday producing and consuming activities. ${ }^{32}$ Yet, this feature is not unique to this present crisis. 'Transformative reconciliation' always has to come into being when human relationships of conciliation spiral out of control and it has to be exercised within them; whether within intimate family relations or in global peace movements in the context of war and conflict. It rejects the alternate idea of an independent process outside the crisis in which elites can do the reconciliation for us.

Third, the role of practices of reconciliation at this phase is to transform the crisis-ridden relationships in which we are entangled and the social and ecological suffering they cause. The aim is to work together to transform unsustainable relationships into conciliatory and sustainable 
ones: that is, to transform the vicious system into a virtuous one that sustains the ways of life of all affected. This cooperative work of transformation is carried out by exercising the shared responsibilities of the members involved.

These responsibilities are 'shared' in a special sense. We cannot see that we have shared responsibilities from within the practices and worldview of the unsustainable relationship to the earth. They are overlooked. From this dominant perspective, we see ourselves as independent of the living earth and our neighbours, with individual responsibilities to look after ourselves and those with whom we choose to contract. We have to free ourselves from these everyday practices and begin to interact with others as our interdependent kin for these more basic shared responsibilities of interdependent relationships to come into view. When we do this, we bring to self-awareness the common good of interdependent conciliation and sustainability and our corresponding responsibilities. We become aware of our interdependency and the co-sustaining responsibilities it entails. ${ }^{33}$

The fourth feature of transformative reconciliation is that means and ends are the same; as acorn to oak tree. The only way to bring about re-conciliation is by conciliatory means because means are prefigurative and constitutive of ends. Reconciliation is really a radical regeneration and re-conciliation of the partners by acting and interacting in a diversity of nonviolent, conciliatory and sustainable ways in our everyday relations with each other and the living earth; by 'being the change'. These ways can be constructive, obstructive and contestatory. In so doing, these members regenerate sustainable ways of life within the interstices of the hegemonic unsustainable system, gradually expanding the circles of participants until it reaches a critical mass and a tipping point of networked practices that transform vicious systems into virtuous ones.

This constitutive view of means and ends is at the heart of the alternative dispute resolution tradition in the West, made famous by Gandhi and his many followers: transformative reconciliation and peace by peaceful and nonviolent means. ${ }^{34}$ Not surprisingly, there are complementary peacemaking traditions in Indigenous civilizations. Here, the people in a crisis situation exercise their "shared responsibilities" by "burying the hatchet": that is, foregoing violence and turning to the path of peacemaking by peaceful preparation, obstruction, noncooperation, and negotiations. They begin to enter into practices of reconciliation by "becoming of one mind": that is, of beginning to become conciliatory in their own interactions. They enter into tough treaty negotiations in conciliatory and friendly ways oriented to transforming the crisis- 
ridden relationships between them. By negotiating in this contentious, yet conciliatory and friendly way, they bring into being peaceful and friendly relationships that sustain them until another crisis irrupts and they return to treaty negotiations and re-conciliate themselves once again. ${ }^{35}$

Hence the term 'peace and friendship treaties' as the name for both the earlymodern treaty negotiations and the relationships they brought into being between Indigenous peoples and settlers. The way of reconciliation - of tough and lengthy peaceful and friendly negotiations - is thus nonviolent, but not non-contentious. Drawing in part on Gandhi, Taiaiake describes the practical philosophy of the peace and friendship way of reconciliation of the crisis in contrast to the ways of either armed resistance or resignation (reconciliation-to): ${ }^{36}$

With the vision of nonviolent contention, Onkwehonwe face the untenable politics and unacceptable conditions in their communities and confront the situation with determined yet restrained action, coherent and creative contention supplemented with a positive political vision based on re-establishing respect for the original covenants and ancient treaties that reflect the founding principles of Onkwehonwe-Settler relationships...with the hope of recreating the conditions of co-existence.

Fifth, reconciliation in this transformative sense literally means to 'conciliate again'. Practices of reconciliation transform the conduct of the partners from the conflict-ridden and unsustainable relationships into the kind of conciliatory and sustainable way of life out of which the crisis emerged.

In summary, the three phases or ways of life can be seen to comprise a meta-cycle of life. First is the basic conciliatory or virtuous way of life that sustains all life on earth and in which disturbances and disputes are resolved by normal practices of conciliation. The second is the unpredictable transformation of this stage into a vicious, unsustainable and seeming irreconcilable cycle that tends towards the destruction of the contending parties. The third phase is the response of extraordinary practices of re-conciliation that, if successful, reconnect the partners to conciliatory and sustainable relationships with each other and the living earth. If reconciliation fails, the crisis-ridden system crosses a tipping-point and collapses in whole or part, taking many of the forms of life with it.

When practices of reconciliation succeed in reconnecting people to conciliatory and sustainable webs of life together, they are not the same as before the crisis. They have gone through a 'learning cycle' by trial and error concerning the conditions that sustain life together on this 
planet. They acquire new skills of re-conciliation and re-sustainability. They are educated and thus more precautionary and better prepared to respond to and cope with the next outbreak of aggressive and unsustainable interaction. They also know each other better. They become friends who have suffered and overcome enormous challenges together. They have overcome alienation and are at home with each other and the living earth ('biophilia'). And so the conciliatory and sustainable cycles of life become paramount once again. ${ }^{37}$

There are many representations of this meta-cycle of life across the civilizations of Turtle Island. The Two Row Wampum nation-to-nation relationship of the Haudenosaunee confederacy, the Peace and Friendship treaties of the Mi'kmaq people, the Royal Proclamation of 1763 and the Treaty of Niagara of 1764, the great treaty traditions of the Plains Cree, and the Raven cycle stories of the peoples of the Northwest coast are some of the better known exemplars. ${ }^{38}$ For my generation of guests on Coast and Straits Salish territories, an iconic representation of this transformative reconciliation cycle is the monumental work of art by Haida artist Bill Reid; the black canoe, called 'the Spirit of Haida Gwaii'. This work of art was crafted by a team of Indigenous and nonIndigenous artists under Reid's supervision during the reconciliation struggles of the Haida to exercise jurisdiction over Haida Gwaii, protect the old growth forests, and work with nonIndigenous allies; and, with Raven at the helm, as a Haida representation of transformative reconciliation-with. ${ }^{39}$

The co-evolution of life on earth has experienced many examples of successful and unsuccessful cycles of conciliation, crisis, and reconciliation, and we are in the sixth now. ${ }^{40}$ The Royal Commission on Aboriginal Peoples suggested that the history of relationships between indigenous peoples and settlers also can be seen in terms of cycles of conciliation, conflict and crisis, and reconciliation; both successful and unsuccessful. The sustainable and conciliatory intersocietal 'middle ground' of the early peace and friendship treaties gave way to periods of treaty violation, marginalization and genocide; then the courageous resilience and resurgence of indigenous peoples in the twentieth century; further encroachment on their territories and resources; and the contemporary attempts to address the indigenous crisis separately by reconciliation through modern treaties and other means. ${ }^{41}$ The contemporary attempts at reconciliation have brought about positive change in several cases, but they have not been transformative. ${ }^{42}$ Hence the continuing dual crisis. My argument is that the dual crisis continues 
because it has not been tackled by the kind of coordinated, reconciliation-with practices outlined in this section.

In the following sections I examine: what the life and human sciences teach us about sustainable and conciliatory ways of living together (Section II); how this knowledge enables us to see how an unsustainable and self-destructive relationship to the living earth and each other, consisting of four global processes, brings about the dual crisis (Section III); and, how the regeneration and resurgence of practices of reconciliation-with can transform the unsustainable relationship (Section IV). That is, I explore the three phases of the meta-cycle of life I have sketched in this section.

\section{Conciliatory and sustainable ways of life: the life systems and human sciences view}

So far we have seen how to understand transformative reconciliation in terms of a meta-

cycle of relationships of conciliation, crisis and reconciliation by drawing on resources in the Hegelian and Gandhian traditions. ${ }^{43}$ We have also seen the way several Indigenous traditions understand reconciliation in terms of a meta-cycle of conciliatory gift-reciprocity relationships, ingratitude and greed, crisis, and reconciliation as regenerating gift-reciprocity relationships anew. There are similar teachings about transformative reconciliation of the social and ecological crises in Buddhist and Christian traditions. ${ }^{44}$ This section is a brief summary of similar explanations of how life sustains life in the life and human sciences. These similarities provide common ground for cooperating in practices of reconciliation.

\section{II.1 Gaia hypothesis}

In the early 1960s Sir James Lovelock, an earth systems scientist, discovered the Gaia Hypothesis. This is the hypothesis that despite the vast changes in the solar energy coming to the earth over the last 3.8 billion years, the vast changes in the forms of life on earth over the same long period, and all the changes in earth, ocean and atmospheric conditions over the same period, the atmospheric conditions and the temperature of the earth have somehow remained in the range that sustains life on earth. The Gaia hypothesis is that the ecosphere, and all the systems of life that compose it, somehow regulate the atmosphere and temperate so as to sustain life. That is, the biotic 
and abiotic ecosphere as a whole is 'self-organising' and 'self-sustaining': often referred to as 'autopoiesis'.

The reason James Lovelock called it the Gaia hypothesis is that William Golding pointed out to him that the Greeks also believed that the earth is alive. They called the spirit of the living earth: anima mundi (the soul, pneuma (breath), spirit, energy or animacy of the living earth). And they took the living earth to be a goddess -Gaia. This hypothesis has survived a number of tests since the 1960s and is now considered not only a hypothesis, but a theory - the Gaia theory. It has been endorsed in one way or another by a majority of the scientists on the Intergovernmental Panel on Climate Change. ${ }^{45}$

This discovery led to attempts to explain how the systems that compose the ecosphere actually regulate the content and temperature of the atmosphere within a fairly broad range of cycles that sustain most forms of life - from ice ages to warm periods, such as the Holocene in which we live. This led to the revolutionary development of life systems theories, complexity theory, and non-linear causality. ${ }^{46}$ For the purposes of those of us who wish to know how we should live within this complex system of systems in ways that sustain rather than damage it the crucially important insight came from Lovelock's colleague, the life scientist, Lyn Margulis. She argued that the Gaia hypothesis is not based on the assumption that the system of systems that compose the ecosphere is itself a purposeful living being that regulates the climate and temperature to sustain life. Rather, the self-sustaining quality of Gaia is an 'emergent property' of the lifesystems or ecosystems that compose the ecosphere. She argues that the Gaia hypothesis is symbiosis on a planetary scale. ${ }^{47}$

There is nothing strange or speculative being smuggled in here. The emergence of new properties in the course of the complex interaction of life systems is the way that life itself has developed in increasingly complex ways. That is, through life systems living-with each other in complex interdependent ways (symbiosis), and giving rise to new life systems (symbiogenesis). Spatially, symbiosis refers to the immensely complex webs or networks that link all forms of life in relationships of reciprocal interdependence. Temporally, these networks are cyclical. They form cycles in which the 'waste' of one interdependent member is always used in some sustaining way by another member, so that nothing is 'wasted' (zero emissions); and at a temporality that enables species and ecosystems renewal. Photosynthesis and the oxygen and carbon dioxide cycles between plants and animals constitute the paradigm of this spatio-temporal quality of symbiosis; 
of reciprocal interdependency and cyclical renewability. It is the basis of the way life sustains life; the animacy of Gaia. ${ }^{48}$

\section{II.2 Symbiosis as the animacy of life}

We can describe and study these endlessly complex and fascinating networks and cycles of symbiosis in terms of the negative and positive feedback loops, tipping points, virtuous and vicious systems, and so on, of systems theory and complexity theory. However, the key feature of the way life sustains life for Margulis is not that the system regulates the conditions of life for its members. Rather, it is the other way round. The plain members and citizens of Gaia sustain it by means of their symbiotic participation in it. And Homo sapiens, as one minor and recent species among millions, are members and citizens just like all others, with ecological responsibilities to participate in ways that reciprocally sustain the networks that sustain us. That is, ecosystems and their members sustain themselves by living in ways of life (lifeways and earthways) that co-sustain the forms of life with which they are interdependent. ${ }^{49}$

Accordingly, 'symbiosis' and 'symbiogenesis' are technical terms in the life sciences for how forms of life live together in mutually supportive ways and, in so doing, give rise from time to time to new symbiotic forms of life (symbiogenesis). These virtuous feedback relationships of mutual sustainability are now seen as the major factor in the evolution of life on earth. Life systems that sustain life symbiotically, in mutually supportive ways, are called "virtuous life systems". Sustainable life systems are not harmonious. They are often far from equilibrium, patchy, full of cheaters or free riders, and subject to perturbations that can cause a life system to tip over into a vicious system. Yet, for all that indeterminacy, their remarkable qualities of resilience enable them to sustain themselves over vast stretches of time. Conversely, life systems that destroy rather than sustain their interdependent neighbours, or destroy the life systems on which they depend, and thus destroy themselves, are called 'vicious life systems'. 50

If vicious life systems were the major factor in evolution, as Western scientists tended to suggest not so long ago, then life on earth would have ceased to exist long ago. But, the opposite is the case. Life has become more complex: that is, symbiosis and symbiogenesis have prevailed most of the time, even recovering from five mass extinctions and periodic ice ages every 100,000 years. Moreover, vicious systems, like virtuous systems, are also far from equilibrium and subject to change. They too are subject to tipping points that transform them into virtuous systems. That 
is, life has resilient powers of 'regeneration' (or reconciliation). Life systems recover by regenerating networks of symbiosis and symbiogenesis within vicious systems, or within the ruins of vicious systems. The third phase of the meta-cycle of life (transformative reconciliation) works within vicious or damaged systems by being the change. Forms of life interact and network symbiotically and symbiogenetically within vicious systems; gradually repairing and transforming them into virtuous systems if they have time to regenerate ${ }^{51}$ Hence, regeneration is similar to reconciliation by means of conciliation in Section I.4. It is autotelic. Here is an example of the recovery of a forest from clear cutting provided by Michael Simpson: ${ }^{52}$

"Living systems do not only reproduce themselves. Their very life processes nourish their habitat and strengthen the conditions of life around them. They thereby create an organism that is larger than themselves or their individual species. When a forest is growing back from a disturbance, herbaceous (non-woody) plants are the first to move in. These plants exude sugars that attract bacteria around their roots. The bacteria in turn exude an alkaline "bioslime" that creates a favorable habitat for themselves as well as for the pioneer plant species. The alkaline condition of the bioslime also allows the bacteria to break down ammonia in the soil into nitrates that are taken up by plants, allowing them to grow vegetatively. This cycle of life creating the conditions for more life continues as the forest gradually grows into a rich, biodiverse ecosystem (ecological succession). Living systems are not only self-regulating but they are relational in so far as they build the conditions of life around them."

The similarity between the systems view of life in the life and earth sciences and the giftreciprocity view of many Indigenous traditions is striking. The Potawanimi biologist Robin Lee Kimmerer draws the connection for us: ${ }^{53}$

'Reciprocity - returning the gift - is not just good manners; it is how the biophysical world works. Balance in ecological systems arises from negative feedback loops, from cycles of giving and taking. Reciprocity among parts of the living earth produces [dynamic] equilibrium, in which life as we know it can flourish.'

Indigenous peoples also have ways of describing the 'far from equilibrium' feature of living systems. As Nuu chah nulth legal scholar Johnny Mack explains, a familiar example of cascading positive feedback loops is when a canoe begins to tip in response to a disturbance and further responses amplify the tipping until the canoe overturns: Hoquotisht. He uses this to describe the disastrous consequences of colonization and neo-colonization of his people. ${ }^{54}$ 
Similarly, the Haida have a mantra to remind themselves of to the tipping-point feature inherent in all living systems. They say 'the world is as sharp as the edge of a knife.' Haida artist Robert Davidson explains: ${ }^{55}$

"Naanii told me that wherever we walk, we're walking on the knife's edge. The world is as sharp as the edge of a knife is a Haida expression. The knife's edge is just on the ground, and if we are not careful, we will fall off: that's how Naanii said it. It guides you on how to live your life. I see the knife's edge as the present moment.

That is, it is always possible that the multiplicity of conciliatory and sustainable relationships in which we live may tip over into unsustainable relationships if selfish, non-reciprocal interaction outweighs gift-reciprocity interaction. The Raven cycle stories of the Northwest coast remind humans how unexpectedly these transformations often occur in everyday life. However, Raven stories also teach humans to be aware of this feature and to learn from the inherited stories of how their ancestors learned - by trial and error - to avoid them or recover from them: to be precautionary. 'If we are not careful' - if we do not take care of each other - we will fall off'.

\section{II.3 Symbiosis in ecological and social systems: towards a new synthesis}

The human sciences have entered into a dialogue with these earth systems and life sciences over the last thirty years. One of the central thesis of this movement is 'integral ecology'. ${ }^{56}$ The common ground on which a dialogue of mutual learning has begun is provided by the shared terms 'symbiosis' and symbiogenesis'. These concepts do not originate in the non-human life sciences, but, rather, have a long history in the human sciences. They refer initially to how human beings have lived together in interdependent relationships of mutual aid and sustainability; and, how various communities have learned to live beside each other in peace and mutual support. Moreover, the 'communities of practice' research has taught us that such informal virtuous, symbiotic social relationships of mutual aid exist within and across every social system; even within the most vicious and damaging social systems. So, the vicious social systems that are embedded within and damaging the ecosystems that sustain life are also embedded within and damaging informal symbiotic social systems that sustain the communities in which we live. ${ }^{57}$

Next, scholars in the humanities and social sciences have begun to realize that we are not dealing with two parallel paths of symbiotic evolution, one for non-human life and the other for human life. Rather, non-human symbiotic ecosystems and human symbiotic social systems are 
now seen as evolving interdependently and reciprocally. They are now seen as interdependent, 'coupled' or, 'co-evolving'. As a result, humans, are now seen and studied as co-evolving and cosustaining apprentices within their social and ecological systems, or what are now called eco-social systems.

This realization is a revolution of the twentieth century. For the previous 500 years, the most Western scholars and scientists saw themselves and their social system as separate from and independent of nature. We now realize that when we are citizens of various social systems, such as states, corporations and markets, we are also Gaia citizens of the ecosystems in which these social systems are embedded and on which they depend. If follows that human beings not only have to think of ourselves as participants in the interdependent ecological relationships that support us. We also have to think of our social systems in the same way - as interdependent - and as coupled to the co-evolution of ecosystems in either mutually sustaining or non-sustaining ways. Hence the term 'eco-social systems'. As William Rees states, 'we can no longer understand the dynamics of either the natural system or the human subsystem in isolation without understanding the dynamics of the other component.' 58

Furthermore, thinking about living systems in this symbiotic and cyclical way brings to awareness the interdependent ecological self, in contrast to the independent, ego-self of our dominant way of life. ${ }^{59}$ From this participatory perspective, we come to realize that if we wish to live well we should live in such a way that our way of life supports the ways of life of those with whom we are related and that they should do the same in reciprocity. We also realize that if we are suffering, it is probably because we are not living in ways that support such mutually supportive networks. This way of life is neither altruistic nor egoistic, for that debilitating distinction rests on the presupposition that organisms are independent and self-sufficient to begin with.

Despite the individualistic and competitive relationships of the dominant formal economy, we are participants in multiple, informal social systems of this symbiotic kind. Relationships within families, neighbourhoods, communities of practice with fellow workers, and an array of social networks are often symbiotic. Many psychologists and sociologists argue that informal, symbiotic relationships are the basis of the health and well-being of all communities and their member; yet unnoticed by the dominant competitive ethos. They even describe them as gift-gratitudereciprocity networks. ${ }^{60}$ 
Finally, this realization has brought about a revolution in the field of ethics. Rather than seeing the realm of ethics consisting of the ways of being with and within the complex communities of relationships that humans inhabit with others humans - past, present, and future - and with the spiritual realm, it is now seen by many to encompass the human relationships with all the nonhuman fellow members of their biotic communities and Gaia as a whole. ${ }^{61}$ Here again, Leopold is a pioneer: 62

All ethics so far evolved rest upon a single premise: that the individual is a member of a community of interdependent parts. His instincts prompt him to compete for his place in the community, but his ethics prompt him also to cooperate (perhaps in order that there may be a place to compete for). The land ethic simply enlarges the boundaries of the community to include soils, water, plants, and animals, or collectively: the land.

An ethic, ecologically, is a limitation on freedom of action in the struggle for existence. An ethic, philosophically, is a differentiation of social from anti-social conduct. These are two definitions of the same thing. The thing has it origin in the tendency of interdependent individuals or groups to evolve modes of cooperation. The ecologist calls these symbioses.

The next step for the life sciences and human sciences working together in community-based research networks is the practical, transformative step of designing and implementing new ecosocial systems and transforming existing unsustainable eco-social systems so they sustain rather destroy themselves and the ecological life systems on which they depend. This is the task announced by Fritz Capra in Section I.2. However, as we have seen, if this task is to be successful it has to bring together the two projects of reconciliation in addressing the ecological and the Indigenous-non-Indigenous crises. This is the topic of the Section IV. Before it can addressed, we need to understand the unsustainable relationship to the living earth at the root of both crises.

\section{The Unsustainable system}

\section{III.1 Belonging-to versus mastery-over}

Given the convergence in understanding how life sustains life on earth, it is not surprising that traditional indigenous knowledge and western life systems knowledge also convergence on the underlying non-linear causes of the dual crisis in our relations with each other and the living earth. For many indigenous people the major factor is captured in the mantra, 'the earth does not 
belong to us. We belong to the earth, mother earth.' As we have seen in Section I, to say that we belong to the earth is to say that humans and their eco-social systems are plain, interdependent members and citizens of the living earth with responsibilities of taking care of the gift-reciprocity ecological and social relationships that take care of us. On this Heshook-ish Tsawalk view, indigenous peoples see and experience themselves as participatory apprentices within and with the living earth who have co-evolved by trial and error along with the regional ecosystems they inhabit and learn from. They have complex 'property systems', but these consist of responsibilities of caretaking and reciprocity. This is how Homo sapiens have co-evolved for roughly 95 per cent of their brief time on earth. ${ }^{63}$ In contrast, to forget this relationship and it responsibilities and to treat the earth as belonging to us, as our property, is irresponsible and vicious. Ojibway Elder Basil Johnston says this is like claiming property in your own mother; mother earth ${ }^{64}$

Accordingly, the dual crisis is brought about by the contrasting property system that was brought to Turtle Island by the settlers. This specific and unique property system is based on the presupposition that the earth belongs to humans as their commodifiable private property, for sale on the market like any other commodity. ${ }^{65}$ It began in England with the Enclosure movement and was spread around the world by Western imperialism and colonization. It was celebrated by Adam Smith and Karl Marx, and their many followers, as bringing civilization to uncivilized peoples through stages of development. Since the earth is the property of the members of this system, it appears to them as if they are separate from or independent of it, and in a relationship of mastery, control and often conquest. It also brings with it an attitude of towering and unquestionable superiority over Indigenous peoples and of the so-called civilizing duty to impose the system over them and their lands. ${ }^{66}$ No non-Indigenous person diagnosed and began to call into question this dual attitude of mastery over nature and indigenous peoples better or more systematically than Franz Boas in The Mind of Primitive Man in 1911.67 In the 1940s Aldo Leopold was among the first generation in North America to argue that this property system and presumption of mastery was both false and destructive of the ecological and social basis of life. He developed his participatory land ethic in response. ${ }^{68}$ At the same time (1944), Karl Polanyi began to analyze this unique property system as a global system and to compare it with other property systems, including indigenous systems (economic anthropology). This gave him a comparative and critical distance that was unavailable to earlier critics and opened a pathway to the social, ecological and 
Indigenous criticisms of the global system today. He called the development of this system the great disembedding and transformation. ${ }^{69}$

\section{III.2 The great transformation}

Polanyi argued that during this great transformation humans have been disembedded from participation in the symbiotic ecological and social relationships that sustain life and re-embedded in abstract and competitive economic, political and legal relationships that are dependent on, yet destructive of, the underlying interdependent ecological and social relationships. This great disembedding from basically virtuous and conciliatory systems and re-embedding in vicious and unsustainable systems takes place in four major processes over the last 300-400 years called, successively, civilization, modernization and globalization.

First, the peoples who are embedded in symbiotic ecological and social relationships are dispossessed of this way of life and the territories in which it is carried on; first by the enclosure of the commons in England and then by the forceful dispossession of indigenous peoples throughout the non-European world; often referred to as the second (global) enclosure. In Canada, despite almost a century of nation-to-nation treaty federalism among roughly equal partners, the Indian Act, a vast administrative dictatorship that governs every detail of Indigenous life, was imposed over Indigenous people and their lands without their consent, in 1876, as the expression of jurisdiction given in s. 91(24) of the British North America Act, passed by the Imperial Parliament in 1867 (now referred to as the Constitution Act, 1867). This colonial system was and continues to be warranted by the fictitious assertion of Crown sovereignty and underlying title over Indigenous peoples and their lands. ${ }^{70}$ Under this genocidal system, Indigenous peoples' traditional ecological and social knowledges and complex eco-social systems have been discredited and criminalized as 'uncivilized'. They have been removed to tiny reserves and residential schools and subjected to endless policies of assimilation to 'civilization' or face marginalization. Despite near extinction, many indigenous peoples have continued to practice and sustain their ways of life, and, with the aid of well-meaning settlers, contested and modified the system. ${ }^{71}$

The second process is to impose an ownership relation to the land by the spread of western legal systems of commodifiable property, thereby transforming earth into property. Polanyi describes the privatization of land as a 'fictitious commodity' because land is not an extractable 
commodity produced for sale on the market. What we now treat as extractable, commodifiable and exchangeable "natural resources" are, as we have seen, interdependent co-participants in the symbiotic webs and cycles of life that sustain life on earth.

Relating to the living earth as a storehouse of commodifiable resources disembeds them from these interdependent ecological relationships and re-embeds them in the abstract and competitive relations of the global market system. The natural world is radically transformed by continuous processes of extraction and commodification. The result of 'development' under this system is the destruction of the webs of interdependent ecological relationships that sustain the natural and human world, giving rise to the environmental crisis and climate change. ${ }^{72}$ Yet, the damage that this complex set of processes causes to the ecosphere all along the chains of dispossession-extraction-finance-commodification-production-consumption-and-waste disposal is treated as 'external' to the systemic relationship that is responsible for it.

Once the means of the reproduction of human life are placed under the ownership of corporations within systems of competition, the third process is to treat the productive capabilities of human beings as commodities for sale on the labour market by the spread of western contract, labour and corporate law. This kind of commodification dis-embeds human producing and consuming capabilities and activities from the surrounding social and ecological relationships in which they take place and re-embeds them in abstract, competitive and non-democratic global market relationships. Polanyi describes the commodification of the productive capabilities of individual humans as the second fictitious commodity.

It is fictitious because abilities to work together and sustain ourselves are not commodities made for the market. These capabilities are, as we have seen in the previous section, the cooperative response-abilities and sustain-abilities through which we humans participate in the social and ecological systems that conciliate and sustain life on earth. They are the capabilities through which we belong to the land and are grounded in it. Yet, they are now treated as abstract capabilities that we as separate individuals 'own' (self-ownership); and, by selling the use of these abilities to a corporation, they become the means by which we insert ourselves in the global market system. The underlying informal social systems that producers and consumers live in and which sustain them - such as families, communities, first nations, networks, and so on - are treated as 'external' to the market system. The result of 'development' under this system is the destruction of the webs of interdependent social relations of mutual aid that sustain human communities, 
giving rise to the well-known forms of social suffering of modern life: alienation and anomie, the horrendous inequalities in life-chances, and the planet of slums and gated communities in which we find ourselves. ${ }^{73}$

Fourth, during the same processes, the intersubjective, everyday human powers and responsibilities of local self-government are extracted from their local practices and alienated to centralized, representative governments through competitive electoral systems in which political parties compete for individual votes in the electoral marketplace. This fictitious transfer of powers of self-government atomizes citizens into independent voters on the one hand and renders representative governments dependent on powerful actors in the production system for taxes, jobs, funding and, thus, re-election on the other. In these systems of 'economic democracy', subjects expect representatives to govern for them. The damage this does to learning and exercising reciprocal responsibilities of participatory democratic self-government with fellow citizens in their social and eco-regions is yet another externality. ${ }^{74}$

Polanyi predicted that the long-term result of this great transformation would be the demolition of society and the destruction of the environment. ${ }^{75}$ Despite Polanyi's warning and hundreds of others, this competitive system, or, more accurately, assemblage of four main processes, continues to expand. As systems theorists explain, it has become the major non-linear cause of the ecological and social crises. ${ }^{76}$

Briefly, corporations are caught up in a competitive system in which they must continuously extract and exploit natural and human resources at the lowest possible price and at maximum speed in order to make a profit or go under. Any damage to the environment and communities in which they operate are treated as external and off-loaded to governments. Individuals, communities, and governments are constrained to compete for these corporations, because they fund their campaigns, bring jobs to the electorate and provide the taxes that enable governments to provide basic services and repair the damage they do to social and ecological systems. If governments try to internalize the externalities, regulate and charge the corporations, corporations are legally protected from 'interference'; and they can move to more compliant countries or they take the government to international courts under the system of global law that now overrides national governments. Transnational corporations, institutions of global governance, complaint states, and networkization work to expand the property system and a massive global military network of wars and war preparation protects it from the diverse forms of 
resistance it encounters. As non-renewable resources become scarce, it becomes more expensive and destructive to extract and exploit them, and, it becomes more difficult to regulate the race for what's left. Even renewable resources are depleted or destroyed because the temporality of market competition and development is faster than the natural cycles that renew aquifers, fish, forests and oceans. $^{77}$

\section{III.3 Understanding the vicious system}

Over the last century there have been struggles over the first process (struggles of Indigenous peoples), second process (decolonization and ownership of the means of production), third process (global inequality, antagonism and destruction of self-sustaining communities), and fourth process (for local participatory democracy). These diverse struggles have brought about important reforms and modifications, and they have made the processes they contested more interactive, contestatory, uneven and unpredictable, rather than unilateral, developmental and inevitable (as earlier theorists portrayed them and some still do). Except for the first, Indigenous struggles, these struggles have been oriented towards gaining power within and modifying the processes of modernization, by reform or revolution; not towards transformation and reconciliation-with.

We can now see that the error and injustice of the first process is of fundamental importance. This is the ongoing dispossession and alienation of human communities from their participatory ways of being in the living earth as plain members and responsible citizens, and the discrediting of the participatory ways of knowing that go along with them This process provides a fictitious mis-representation of the Indigenous civilizations it destroys and a fictitious misrepresentation of the civilization that re-possesses the living earth. Indigenous cyclical ways of being and knowing are not only discredited as primitive errors from which moderns have nothing to learn. They are also assimilated into the new fictitious narrative and redescribed as the lowest and poorest stage of human, linear development, which is presented as universal progress. The idea of alternative, gift-reciprocity civilizations, oriented to the sustainability and well-being of their human and more-than-human members, is treated as an anthropological curiosity. Dispossession from the living earth is thus not only a monumental ongoing social injustice to indigenous peoples. It is also a monumental ongoing ecological, epistemological and social injustice to one and all. ${ }^{78}$ 
However, since the 1950s we have seen the networking together of struggles for Indigenous, social, and ecological justice in a multiplicity of sites and ways as the escalating destructive effects of the dual crisis become more manifest and better researched and understood (as in Sections I \& II). At the core of these multiple movements is the dawning realization that the first process of dispossession, disembedding and discrediting of the participatory-reciprocity view of life is the crucial precondition of the rise of the unsustainable system and the dual crisis, not one of the other three processes, as earlier critics presumed. ${ }^{79}$ For example, the sustainability of communities and the well-being of their members depends upon underlying gift-reciprocity social relationships of mutual aid, and these on similar ecological relationships. When these are destroyed, inequality and violent antagonisms increase. There is no solution to global inequality and violent conflict without addressing these underlying conditions. ${ }^{80}$ These new networks have not yet been transformative reconciliation-with each other and the living earth. They have been constrained to reconciliation-to the more powerful vicious global system they question and contest. Yet, as I will argue in Section IV, they provide the regenerative permaculture of practices of transformative reconciliation-with.

For example, the struggles, reforms and modifications over reconciliation of indigenous and non-indigenous people and peoples have certainly modified the first process, including the way Crown sovereignty and underlying title are exercised through Parliament, the courts and the Indian Act - from direct rule to indirect, consultative, contestatory and interactive hegemonsubaltern rule. However, these great changes have modified but not transformed the four processes of the great transformation, as the right to infringe aboriginal title for the sake of development and the pre-set conditions and economic certainty of treaty negotiations illustrate.$^{81}$ Indeed, in several cases the result of lengthy litigation or negotiation has been indebtedness and thus deeper dependency on the vicious system (similar to the debt trap that the Third World faced after decolonization). Also, the majority of struggles, modifications and reforms over pollution, global warming and ecological justice over the same period have had a minor effect on global warming and the larger ecological crisis so far.

If the rise of the four processes of disembedding and re-embedding is examined in the light of the conditions of sustainability and well-being of social systems and ecosystems presented by the life, earth and human sciences (symbiotic networks and cycles) and by traditional Indigenous sciences (gift-reciprocity networks and cycles), as I have already foreshadowed in my description 
of the four processes, the precise nexus of conditions that sustain the vicious system and its dual crisis and how to transform them come into clear view. As Polanyi pointed out, in contrast to all examples of sustainable market civilizations in the past, the modern economic, political, legal, technological, and military system became disembedded from within the virtuous background indigenous and non-indigenous ecosocial systems of the world (processes 1,2 and 4) and the background ecological systems (process 2) on which it and all life depend. The four fictions hide this disembedding by misrepresenting the participatory members of these symbiotic systems as if they are separable, independent commodities (natural and human resources), like any other commodity made for the market. The system then acts in and on the living earth and living communities in accordance with this misrepresentation, economically, politically, legally and technologically (the so-called 'autonomous' public and private spheres of modernization). The legitimation of this estranged form of life is reinforced by the secondary explanations of it in terms of linear progress, development, and so on.

Thus, the fictions conceal the great transformations that has taken place. Unsustainable, non-reciprocal extraction, rather than sustainable, reciprocal regeneration, has become the dominant relationship to living earth and social systems. Externalization and independence are seen as prior to internalization and interdependence. Unsustainable linear economics, based on unlimited growth, waste disposal and external regulation, has become dominant over sustainable, cyclical economics. In interdependent, cyclical and regenerative ecological and social systems everything is connected, so nothing is external and there is no waste. The emissions of members are always used by other members in all their activities. Everything recycles. Thus, they are 'cradle to cradle' systems like trees in forests from seed to nurse log. In contrast, our present system of unlimited extraction out of and waste disposal into somewhere external is a 'cradle to grave' system. ${ }^{82}$

As we can see, the result is a 'super-predatory' system. It depends on, and is nested within, the informal social and ecological relationships that sustain life on earth. Yet, at the same time, it preys on them in an extractive, linear and non-reciprocal way. Yet, at the same time, it treats the damage it does to them as external and independent. Like all super-predatory systems, human or non-human, it destroys the life systems that sustain it faster than they can regenerate. If 'business as usual' continues the system will destroy the social and ecological conditions that sustain life for most human beings and for hundreds of thousands of other species and ecosystems (the sixth mass 
extinction); a set of processes that is well underway. When humans respond simply by trying to regulate the system by technical means of the political and legal institutions of the system, these have been insufficient, primarily because these institutions are dependent on the system's growth. If humans respond by recognizing the damage and trying to internalize the full costs to repair all the damage it is causing, the system would be shown to be unprofitable and it would collapse. That is, it is economically irrational, as well as socially and ecologically irrational. ${ }^{83}$

Despite the mounting scientific evidence of unsustainability and self-destructiveness, the global system persists for several reasons. The four fictions that legitimate the processes continue to be taken for granted for the most part. The secondary explanations of progress as linear development, unlimited growth, freedom as free trade, and so on continue to hold sway despite many refutations. But, the main reason is simply that the majority of the world's population are subjects of, dependents on, and in financial debt to the global system for their livelihood and wellbeing to varying degrees, including those who are working hard to question, contest and change it in various ways. That is, we reproduce it through most of our everyday activities of work and play, even when we try to act otherwise as much as possible. It is our paramount way of life - our way of acting - that reproduces the system. We are conscripts of the vicious system whether we accept or critique the scripts that legitimate it ('domination without consent'). ${ }^{84}$ As a result of acting accordingly we cannot help but acquire the corresponding background form of subjection and subjectivity: of disclosing and perceiving the world around us. Despite our eco-social and ecological interdependency, we perceive ourselves from within the disembedded global system: that is, as independent of the life-sustaining eco-social and ecological webs of life that appear to be external from within the vicious system. As conscripts, the fictional misrepresentation of the four processes becomes our pre-reflective perception of the world in which we live. ${ }^{85}$

Therefore, the way to change the system is not only to think differently, as we have been doing so far. It is also necessary to act differently. This involves freeing ourselves to some extent from the ways of acting that reproduce the unsustainable system and its way of perceiving the world, and then beginning to act as plain, participatory members and citizens in and of the damaged and endangered symbiotic ecosystems and informal social systems we inhabit. As people act in participatory, interdependent and mutually sustainable ways in more and more relationships of their lives, the way that the world is perceived and disclosed to them begins to change accordingly. In so doing, they begin to experience and be moved in turn by the gift-reciprocity animacy of life 
itself. This regenerative movement of potentially transformative reconciliation-with, in its countless manifestations, is called the great 'reconnection'.

\section{Reconnection and Transformative Reconciliation}

\section{IV.1. Raven brings the light}

Given the previous section, how can indigenous and non-indigenous people begin to perceive our eco-social systems in interdependent and cyclical ways and begin to become plain members and citizens of them with reciprocal dispositional responsibilities to sustain them and the wellbeing of their members? Robert Davidson provides an exemplary indigenous way of bringing about this transformation. He tells a contemporary story of how Raven, the transformer, tries to bring to light the damage that a vicious way of life is causing to the people who are caught up in it, yet who mis-perceive it and so continue to reproduce it. Raven removes one eye from each villager as they are sleeping so they will see with only one eye when they awake. In so doing: ${ }^{86}$

Raven creates an imbalance with his voraciousness, because if you take away one eye, you take away the depth of vision. Right now on Haida Gwaii, there is logging in very sensitive areas where the marbled murrelets live. We are so ravenous, so voracious. There is no thinking of the next generation - and even then, we are not fulfilled.

To view the world from the perspective of the dominant extractive system is to be one-eyed; to lose our depth of vision: that is, of being able to see the extractive system as a recent transformation of a much older and deeper conciliatory and sustainable system that endures and underlies this unsustainable system. When villagers re-awake and see with two eyes, they are able see the interdependency between the forests and the marbled murrelets that sustains life. The oneeyed view also fails to think ahead to the conditions that sustain future generations. It is self-centric rather than kincentric. Moreover, this ego-centric way of life is never satisfied: 'we are not fulfilled'.

One way that indigenous people on the Northwest Coast regain their depth of vision in the middle of a crisis is to gather together, wear the masks of the life-forms affected, dance and sing like them, and tell stories of how they have recovered from damaging animals, plants and ecosystems before. In so doing, they remind themselves what it is like to think and act like the animals that masks represent and see their interdependent world from their perspectives, thus 
seeing in contrast the damage their one-eyed way of life does to the interconnected world. As LeviStrauss realized, 'the essential function of the mask is to be the transformation of the individual wearer into another being' ${ }^{87}$ This practice of deep empathy, of inhabiting the ways of being of one's human and non-human relatives in order to see what one is doing wrong, especially seeing non-reciprocation (such as over-harvesting) or non-reciprocation, is one of the oldest sustainability practices of Homo sapiens. ${ }^{88}$

However, one can perform the mask dances and stories only if she or he already has the experience of living with animals and ecosystems, learning their interdependent lifeways, and how to live with them. For example, Aldo Leopold could 'see like a mountain', rather than like an extractor, developer, consumer or disposer, only after years of living as a forest ranger. ${ }^{89}$ Yet, our extractive and species-centric way of life severs its members from this living interconnection with all forms of life. So, the way to depth of vision for those of us who have been disconnected is through practices of 'reconnection'. ${ }^{90}$ Reconnection is a task for both indigenous and nonindigenous people, yet in different ways. This is how Davidson sees reconnection with Haida ways of knowing, learning from, and then regenerating mother earth; and doing so in partnership with non-Haida citizens of Haida Gwaii: ${ }^{91}$

We are now coming full circle, we are the fourth generation in which the white people have instilled their ideas and values, and denied our way of life, without any knowledge or concern of who we were and where we were coming from. It is our generation that is making the attempt to bridge the gap, to reclaim our identity, our cultural values, the philosophies developed by our ancestors for generations and generations. We are also making a great effort to reconnect with the land. The land is the very foundation of our culture. It is our homeland. We were born into it. We are the stewards: it is our right and responsibility to maintain, nurture and preserve it for the future.

It is important to remember that the Indigenous peoples of the Northwest Coast have been through a similar dual crisis before. During the period of dispossession and dislocation from 1800 to 1880 ninety percent of their populations were decimated by smallpox brought by the settlers. Then as now, they turned to their stories and teachings of cyclical regeneration to survive and recover. ${ }^{92}$

\section{IV.2 Reconnection by way of practices of reconciliation}


Humans have not been completely disconnected from social and ecological relationships of interdependency. Rather, we have become conscripts of a vicious social system that operates as if it were disconnected. Accordingly, 'reconnection', if it is to be transformative, means: becoming self-aware of our discursive and non-discursive subjection to this system; freeing ourselves from its hold on our perception and behaviour by moving around so we can begin to experience our ecosocial interconnection and interdependency; seeing the social and ecological suffering that our vicious system causes; and taking up our eco-social responsibilities of earth-learning, repair and regeneration that we have as plain members and citizens of the commonwealth of all forms of life on earth. These four steps constitute nonviolent practices of transformative reconciliation-with each other and the living earth. They 'realize' transformative reconciliation in the double sense of becoming aware of what it involves and bringing it into being by changing one's way of life, as the quotation from Davidson illustrates. This is also the way reconnection and reconciliation are conceptualized in other traditions. ${ }^{93}$

There are many particular ways in which these transformative steps can be enacted. However, they all share the five features of transformative reconciliation set out in Section I.4. Like Raven in the Davidson example, the massive empirical evidence, scientific reports and academic and non-academic writing bring the crisis to awareness (feature one). The central feature that then animates practices of transformative reconciliation is feature four - being the change by acting and interacting in conciliatory, symbiotic and co-sustainable ways in our everyday activities with each and the living earth. This is the earth teaching that we have learned from Indigenous traditions in Section I and the life and human sciences in Section II.

The reason why the means of transformation of the vicious system have to be reconnective practices of conciliatory and sustainable cooperation is that the means sow the seeds of the end. This is the way that life systems recover from crises in the three meta-cycles of life (Sections I.4, II.2). The practical reason for this constitutive relationship between means (practices of reconciliation) and ends (transformation) is that we cannot possibly bring to light and know what counts as responsible reciprocation (repair and regeneration) unless and until we begin to interactwith and within eco-social systems as cooperative and co-evolving participants and learn our way around. This participatory way of being in the world discloses the world as a living interdependent world; whereas, in contrast, our extractive and mastery-over way of being discloses the world as an external storehouse of proto-commodities. ${ }^{94}$ 
As we have seen, the participatory way of being in the world brings to light the way that life sustains life, and thus the way of transformative reconciliation. This is expressed in the view that co-sustaining symbiosis is the major factor in the co-evolution of life on earth. Living beings sustain themselves by living in ways that co-sustain the interdependent ecosystems and eco-social systems that co-sustain them. The way people come to know what ways of life co-sustain their interdependent neighbours, human and more-than-human, is to enter into dialogues of mutual learning with them. The members learn from each other, co-operate and thus conciliate and reconciliate the mutually supportive relationships between them..$^{95}$ If such cooperative practices of reconciliation are to be transformative and overcome the injustices of dispossession in Section III.2, non-indigenous peoples have to enter into cooperative relationships of mutual learning and cooperation with indigenous peoples, in accordance with their laws and ways of learning and cooperating, when they are living, working on, or affecting their traditional territories. The convergence of Indigenous and Western knowledge now makes this form of cooperation possible and mutually enlightening (Section II). ${ }^{96}$

Everyone can engage in practices of reconciliation here and now. There is no privileged position or class. Everyone can become aware of and work on the three types of eco-social relationships in which they find themselves in their everyday lives: the relationships they have with their selves (practices of the self), with other human beings (communities of practice), and with the living earth (earth practices). Like the recovery of an ecosystem after clear-cutting, this begins by becoming aware of and connecting with the symbiotic ecosystems and informal ecosystems that continue to exist and sustain life despite super-predation by the vicious global system. ${ }^{97}$ Moreover, it involves becoming aware of and connecting with the eco-social ecology generated by the more recent practices of reconciliation over the last decades and learning from their successes and failures. ${ }^{98}$

Valerie Napoleon and Hadley Friedland have developed one exemplary way of doing this. ${ }^{99}$ They invite members of a community to get together and map the relationships they find themselves in; both the vicious relationships of the dominant system and the virtuous relationships they inhabit. They then discuss how they can work to change vicious and unsustainable relationships and to regenerate and scale out the virtuous relationships into expanding networks. These activities involve ethical practices of the self (self-change); various ways of reforming the vicious relationships they inhabit from within the practices and institutions available to them 
(reform); as well as the more confrontational ways of nonviolent protest, contestation, civil disobedience, boycotts and so on (contestation). They also involve innovative practices of disengaging from the dominant system as much as possible, re-appropriating and exercising the human capacities of self-organization and self-government in their producing and consuming activities in local, co-sustaining networks and cycles (constructive programs). These are neither exclusively reconciliation practices from above nor below, but, as they succinctly put it, 'everywhere and everyday'. ${ }^{100}$ In these four types of gift-reciprocity practices and networks of reconciliation-with, indigenous and non-indigenous partners engage in mutual learning, reforming the dominant institutions from within, tradespeople and inventors developing green technologies, cyclical economic organizations, local food revolutions, biomimicry, cradle to cradle technology, architecture and town planning, post-carbon fuels, cooperatives rather than private corporations, fair trade rather than free trade, commoning rather than privatizing the living earth, engaging in shared, land-based and community-based education and research, establishing Indigenous peoples working groups on climate change, and countless other examples. ${ }^{101}$

Some indigenous people engaging these activities prefer to work with their own community and not with non-indigenous partners as much as possible. This is often referred to as resurgence. ${ }^{102}$ Yet, 'resurgence' in this sense consists in reconnecting with and regenerating the living earth and relationship with members of their indigenous community. That is, while the practitioners are often critical of processes of reconciliation-to, their practice consists in community-based practices of transformative reconciliation-with. Respect for these resurgence practices is an important part of the ethics of reconciliation-with. ${ }^{103}$ Others, such as the Haida and the Great Bear Rainforest Alliance, prefer to work with their non-indigenous neighbours, building these relationships of mutual aid as they go along. ${ }^{104}$ There are many kinds of conciliatory and sustainable partnerships between Indigenous and non-Indigenous peoples, and they are possible even in the most polluted and difficult circumstances today. ${ }^{105}$ However, what makes them transformative is that they are based on the gift-reciprocity relationship of interdependency and mutual aid learned from Mother Earth. The early modern peace and friendship treaties and the Two Row Wampum treaty relationship are often used as the model for these partnerships. The reason for this is that the way the partners treat each other in the treaty negotiations manifests the kind of relationship they aim to bring into being among their respective peoples as a result of the negotiations. ${ }^{106}$ Moreover, the revitalization of indigenous legal orders empowers indigenous 
people to relate to each other, their non-Indigenous neighbours, and mother earth through their legal and governmental traditions. ${ }^{107}$

The repair, regeneration, creation and scaling-out of these gift-reciprocity practices, networks and cycles of reconciliation-with can be transformative, both locally in the short term and globally in the long term. They grow on the basis of the gifts that have been given to us by the living earth and those who came before us, and they will continue to grow on the basis of what our generations have given in reciprocity. The biggest challenge today is not to design or invent practices of transformative reconciliation. Appropriate sustainable and cyclical ways of knowing and of acting already exist in practice to a significant extent for many areas of human activity. The challenge today is to find ways to connect and coordinate these four different kinds of reconciliation practices in larger webs of gift-reciprocity relationships of mutual learning and mutual support. For none of these kinds of practice is sufficient in independence from the other three. Educational institutions can play an important role in this coordination with the appropriate kind of teaching, learning and research.

No one doubts the enormity of the task of the two projects of reconciliation and the seeming insignificance of the non-violent, human-scale means I am suggesting. However, as we have seen, the alternative means of either violence or mega-projects by elites are part of the dual crisis. As the small, local, symbiotically coordinated webs of steps and practices of reconciliation grow, they first reach tipping points and bring about transformations of vicious relationships locally. These small changes have significant ripple effects, especially on the younger generations who see and hear about them. If these continue to multiply and accumulate here, there and everywhere, they have the potential gradually to reach a point where the global vicious system as a whole is transformed into an assemblage of virtuous ones. Then, once again, conciliatory and sustainable relationships and cycles become dominant, and humans and their relatives begin another metacycle, hopefully having learned how to avoid another massive crisis like the one we are in today. This is how damaged ecosystems incrementally transform themselves and how human civilizations have survived collapse in the past. ${ }^{108}$

The most important feature of this ethical view of reconciliation is that it enables everyone to act responsibly and reciprocally here and now: to realize reconciliation here on earth and with each other to some small extent in every step we take. If this view of life is correct, then some of our interdependent relatives, human and more-than-human, will be moved to reciprocate in 
response. Then, we will be reconnected to and empowered by the cyclical and regenerative animacy of life itself - the greatest power on earth. 


\section{Endnotes to chapter 3: Reconciliation Here on Earth}

${ }^{1}$ The two kinds of reconciliation, formal and informal, overlap in various ways. However, I suggest that specific policies and practices of formal recognition, such as the recommendations of The Truth and Reconciliation Commission, need to be grounded in a broader and more basic kind of informal, cyclical reconciliation, which I call reconciliation-with, if they are to become effective in the long term. Informal reconciliation-with is the living ethos and ecology that sustains formal and specific policies of reconciliation. For a concise synopsis of the Truth and Reconciliation Commission's view of reconciliation, which shows its complementarity, see Paulette Regan, this volume.

${ }^{2}$ Reconciliation with each other 'in all our diversity' refers to practices of reconciliation that are aware of the criss-crossing and overlapping identity-related differences and similarities within and across indigenous and non-indigenous peoples, such as class, race, gender, sexual orientation, place, age, education, and health, as well as the diversity of meanings of indigenous and non-indigenous. I call this intersectional approach 'diversity awareness' (James Tully, Democracy and Civic Freedom (Cambridge: Cambridge University Press, 2008), 291-316. The phrases 'indigenous and non-indigenous' and 'with each other' always refer to this complex lifeworld even though I am not able to analyze the complex diversity of instances of reconciliation in this brief exposition. This approach contrasts with approaches that abstract an ‘indigenous and non-indigenous' binary from the diverse field of lived experience in which it exists. For an excellent introduction to diversity aware approaches, see Gina Starblanket and Heidi Stark, this volume.

${ }^{3}$ For an introduction to the ecological crisis, including climate change, see the Intergovernmental Panel on Climate Change (IPCC), Climate Change 2014: IPCC Fifth Assessment Synthesis Report, www.ipcc.ch/pdf/assessment-report/ar5/syr/SYR_AR5_FINAL_full.pdf, James Lovelock, A Rough Guide to the Future (New York: Penguin 2014), Craig Dilworth, Too Smart for Our Own Good: The Ecological Predicament of Humankind (Cambridge: Cambridge University Press, 2010), Peter Sale, Our Dying Planet: An Ecologist's View of the Crisis We Face (Berkeley: University of California Press, 2012), Richard Heinberg \& Daniel Lerch, eds., The Post-Carbon Reader: Managing the $21^{\text {st }}$ Century's Sustainability Crises (Healdsburg, CA.: Watershed Media, 2010). See Section III. 
${ }^{4}$ See Kim Sterelny, The Evolved Apprentice: How Evolution Made Humans Unique (Cambridge MA: MIT Press, 2012), Nancy Turner, Ancient Pathways, Ancestral Knowledge: Ethnobotany and Ecological Wisdom of Indigenous People of Northwestern North America (Montreal: McGill-Queens University Press, 2014), Craig Dilworth, Too Smart for Our Own Good: The Ecological Predicament of Humankind (Cambridge: Cambridge University Press, 2010), 52-75, Robin Wall Kimmerer, Braiding Sweetgrass: Indigenous Wisdom, Scientific Knowledge, and the Teachings of Plants (Minneapolis: Milkweed Editions, 2013).

${ }^{5}$ See Sections III.3, IV.2.

${ }^{6}$ The first person to expose this double injustice systematically was Franz Boas, The Mind of Primitive Man (New York: The MacMillan Company 1922 [1911]). See James Tully, 'Rediscovering the World of Franz Boas: Anthropology, Equality/Diversity, and World Peace', Ned Blackhawk \& Isaiah Wilner eds., Indigenous Visions: Rediscovering the World of Franz Boas (New Haven: Yale University Press, 2016, forthcoming).

${ }^{7}$ For a synthesis, see Fritjof Capra \& Pier Luigi Luisi, The Systems View of Life (Cambridge: Cambridge University Press, 2014).

${ }^{8}$ This is associated with the recognition of Indigenous peoples ways of knowing (and being), often referred to as traditional ecological knowledge and wisdom (TEKW), as equal in epistemic status to Western scientific knowledges, and the recognition of Indigenous peoples as peoples with the right of self-determination in international law, in accordance with their ways of knowing and being, in the United Nations Declaration on the Rights of Indigenous Peoples. ${ }^{9}$ Zoltan Grossman \& Alan Parker, eds., Asserting Native Resilience: Pacific Rim Indigenous Nations Face the Climate Crisis (Corvalis: Oregon State University Press, 2012).

${ }^{10}$ For an introduction to this vision of education, see Sean Esbjorn-Hargens \& Michael E. Zimmerman, eds., Integral Ecology: Uniting Multiple Perspectives on the Natural World (Boston: Integral Books, 2009), Fritjof Capra \& Pier Luigi Luisi, The Systems View of Life (Cambridge: Cambridge University Press, 2014).

${ }^{11}$ Fritjof Capra, The Hidden Connections: A Science for Sustainable Living (New York: Anchor Books, 2004) 230.

${ }^{12}$ See Sections I.4, III.3, IV.2.

${ }^{13}$ Robert Williams Jr., Linking Arms Together: American Indian Treaty Visions of Law and Peace 1600-1800 (Oxford: Oxford University Press, 1997), Michael Asch, On Being Here to 
Stay: Treaties and Aboriginal Rights in Canada (Toronto: University of Toronto Press, 2014), Michael Asch, this volume.

14 John Borrows, Freedom and Indigenous Constitutionalism (Toronto: University of Toronto Press, 2016), 221. See John Borrows, this volume, Aaron Mills, “The Lifeworlds of Law: On Revitalizing Indigenous Legal Orders Today”, McGill Law Journal (2016) 61:4, forthcoming, and Aaron Mills, this volume, Winona LaDuke, All Our Relations: Native Struggles for Land and Life (Cambridge, MA: South End Press, 1999).

${ }^{15}$ Cary Miller, 'Gifts as Treaties', American Indian Quarterly, Spring 2002, 26, 2, 221-45. Robin Wall Kimmerer, Braiding Sweetgrass: Indigenous Wisdom, Scientific Knowledge, and the Teachings of Plants (Minneapolis: Milkweed Editions, 2013) is an exploration of earth teachings of gift-reciprocity and their roles in establishing sustainable, gift-reciprocity social relationships. ${ }^{16}$ Robin Wall Kimmerer, Braiding Sweetgrass: Indigenous Wisdom, Scientific Knowledge, and the Teachings of Plants (Minneapolis: Milkweed Editions, 2013) 303-310, 380-384. For similar gift-reciprocity cycle stories on the Northwest coast, see Ron Trosper, Resilience, Reciprocity and Ecological-Economics: Northwest Coast Sustainability (London: Routledge 2011), Isaiah Lorado Wilner, 'A Global Potlatch: Identifying the Indigenous Influence on Western Thought', American Indian Culture and Research Journal 37, no.2 (2013) 87-114. For a recent analysis of the gift-reciprocity relationship and the literature on it in the Western tradition, see Marc Hénaff, The Price of Truth: Gift, Money, and Philosophy, tr. Jean-Louise Morhange (Stanford: Stanford University Press, 2010) 101-290

17 Taiaiake Alfred, Wasase: Indigenous Pathways of Action and Freedom (Toronto: University of Toronto Press, 2009) 13-17. This is his adaptation of the Rotinoshonni Thanksgiving Address in the Haudenosaunee Environmental Task Force's 'Greetings to the Natural World', in Haudenosaunee Environmental Restoration: An Indigenous Strategy for Sustainability (Cambridge: Indigenous Development International, 1995).

${ }^{18}$ George Clutesi, Potlatch (Sidney: Grey Publishing, 1969), 3.

${ }^{19}$ Nancy Turner, The Earth's Blanket: Traditional Teachings for Sustainable Living (Vancouver: Douglas \& MacIntyre, 2005) 69-95.

20 'Independence' in this section refers to the family of views that derive from the premise that independence is ontologically prior to relationships of interdependence and a moral and political 
ideal. It does not refer to the kind of 'contextual independence' agents have or acquire in awareness of and respect for life-sustaining relationships of interdependence.

${ }^{21}$ See, respectively, Mathis Wackernagel \& William Rees, Our Ecological Footprint: Reducing Human Impact on the Earth (Gabriola Island: New Society Publishers, 1996), Alan Drengson \& Bill Devall, eds., The Ecology of Wisdom: Writings of Arne Naess (Berkeley: Counterpoint, 2008) 99-144.

22 David Abram, The Spell of the Sensuous (New York: Vintage Books, 1996).

${ }^{23}$ Aldo Leopold, 'The Land ethic', A Sand County Almanac: With Essays on Conservation from Round River (New York: Ballantine Books, 1966) 237-295. The cyclical view of life sustaining life is at $137-141,188-202$.

${ }^{24}$ For this distinction, see Michael O. Hardimon, Hegel's Social Philosophy: The Project of Reconciliation (Cambridge: Cambridge University Press, 1994) 84-126. This is a helpful guide to the distinction between the two senses of 'reconciliation', reconciliation-to and reconciliationwith. However, the five criteria of transformative reconciliation-with that I employ are not identical to Hegel's, but have been crafted in light of other traditions of transformative reconciliation of unjust relationships, especially the Gandhian tradition and the Indigenous traditions of the Northwest coast. There have been many criticisms of the formal processes of reconciliation-to in Canada, but most of these have remained within the background assumptions of reconciliation-to, and thus their alternatives remain within the unsustainable relationship to the living earth and each other (See Section III). For a definitive critical analysis of the persisting colonial foundations of processes and policies of reconciliation-to from the nineteenth century to today to which I am indebted, see Joshua Nichols, A Reconciliation without Recollection: An Investigation of the Foundations of the Indian Act (Faculty of Law, University of Victoria, Ph.D. Dissertation in progress, forthcoming 2017).

${ }^{25}$ Umeek, E. Richard Atleo, Tsawalk: A Nuu-chah-nulth Worldview (Vancouver: UBC Press, 2004) 117-132, Umeek, E. Richard Atleo, Principles of Tsawalk: An Indigenous Approach to Global Crisis (Vancouver: UBC Press, 2011) 9-78.

26 These disruptions are often unpredictable and can irrupt and transform any conciliatory relationship. In Indigenous traditions it is often the trickster, who initiates such a disruption in order to teach a lesson about sharing, gratitude, responsibility and so on. The Raven cycle stories on the Northwest coast are exemplary (Richard Atleo, Tsawalk 1-22). For a careful analysis of 
how such disruptions break out in human relationships and how they can be transformed by practices of reconciliation in the Buddhist tradition, see Pema Chodron, Practicing Peace in Times of War (Boston: Shambhala 2007). For an introduction to contemporary Anishinaabe trickster (Nanaboozhoo) stories, see John Borrows (Kegedonce), Drawing Out Law: A Spirit's Guide (Toronto: University of Toronto Press, 2010).

27 The terms 'virtuous' and 'vicious' systems are drawn from systems theory and its application to the ecological crisis. See Stephan Harding, Animate Earth: Science, Intuition and Gaia, Second edition (Cambridge MA: Green Books, 2013) 68-91. See Section II.1. It is similar to virtuous and vicious in Indigenous gift-reciprocity (and non-reciprocity) stories.

${ }^{28}$ See Paulette Regan and Kiera Ladner this volume, the reports on murdered and missing Aboriginal women: https://foreignpolicy.com/2016/07/06/the-vanishing-of-canadas-first-nationswomen-harper-trudeau-violence-highway-of-tears-indigenous/ accessed July 202016.

29 John Borrows, 'Interview on Idle No More', CBC Radio, 2014.

${ }^{30}$ Michael Klare, The Race for What's Left: The Global Scramble for the World's Last Resources (New York: Picador, 2012.

${ }^{31}$ Lester R. Brown, World on the Edge: How to Prevent Environmental and Economic Collapse (New York: W.W. Norton, 2011), and references in note 3 above.

${ }^{32}$ See Sections III. 2 \& III.3.

${ }^{33}$ See Section IV.1 \& IV.2.

34 Dennis Dalton, Mahatma Gandhi: Nonviolent Power in Action (New York: Columbia University Press, 2012), Richard Gregg, The Power of Nonviolence (New York: Schocken Books, 1966).

35 See, for example, Jeanette Armstrong and the En'owkin Centre, Penticton Indian Band, B.C., http://www.enowkincentre.ca/home.html, Taiaiake Alfred, Wasase: Indigenous Pathways of Action and Freedom (Toronto: University of Toronto Press, 2009) 45-97, John Borrows, Freedom and Indigenous Constitutionalism (Toronto: University of Toronto Press, 2016) 50-102. 36 Taiaiake Alfred, Wasase: Indigenous Pathways of Action and Freedom (Toronto: University of Toronto Press, 2009) 21, Compare 229-230

${ }^{37}$ Eric Fromm coined the term 'biophilia' in the 1950s to describe this participatory, giftreciprocity ways of being in the world with other living beings. 
38 See, respectively, (Chief) Michael Mitchell, ‘An Unbroken Assertion of Sovereignty', Drumbeat, Anger and Renewal in Indian Country, ed. Boyce Richardson (Toronto: Assembly of First Nations: Summerhill Press, 1989) 105-136, 109-110, Taiaiake Alfred, Wasase: Indigenous Pathways of Action and Freedom (Toronto: University of Toronto Press, 2009) 266; John Borrows, Canada's Indigenous Constitution (Toronto: University of Toronto Press, 2010); John Borrows, 'Wampum at Niagara: The Royal Proclamation, Canadian Legal History, and SelfGovernment', Michael Asch, ed., Aboriginal and Treaty Rights in Canada: Essays on Law, Equity and Respect for Difference Vancouver: UBC Press, 1997) 155-12, Aaron Mills, “The Treaty of Niagara 1764, Political Community and Non-domination: A Perspective from Anishinaabe Constitutionalism on Being Well Together", public lecture at The Treaty of Niagara 1764 and Canadian Constitutionalism Today: Crown/First Nations Relations 250 Years In, sponsored by the Centre for Human Rights and Legal Pluralism and the Aboriginal Law Students’ Association, McGill University Faculty of Law, Montreal, September $15^{\text {th }}$ 2014; Michael Asch, On Being Here to Stay: Treaties and Aboriginal Rights in Canada (Toronto: University of Toronto Press, 2014); Robin Wall Kimmerer, Braiding Sweetgrass: Indigenous Wisdom, Scientific Knowledge, and the Teachings of Plants (Minneapolis: Milkweed Editions, 2013) 3-11; and K'san book builders, We-gyet [Raven] Wanders On: Legends of the Northwest (Saanichton B.C.: Hancock House Publishing, 1977), and Xsiwis (Jane Smith), Placing Gitxsan Stories in Text: Returning the Feathers. Guuxs Mak'am Mik'aax (University of British Columbia, Unpublished Ph.D. Dissertation, 2004), Vernon Wilson, A Post-Delgamuukw Philosophical Feast: Feeding the Ancestral Desire for Peaceful Coexistence (Trinity Western University, unpublished M.A. thesis, 2016).

${ }^{39}$ Ulli Steltzer \& Robert Bringhurst, The Black Canoe: Bill Reid and The Spirit of Haida Gwaii Vancouver: Douglas \& MacIntyre, 1992). The canoe is full of diverse myth creatures with all their crisscrossing and overlapping stories, yet conciliating their differences through nonviolent dialogues. Bill Reid was involved in the Haida assertion of jurisdiction over Haida Gwaii and the protection of the old growth forests while the canoe was being constructed (See Leslie Dawn, 'RE: Reading Reid and the "revival"', Bill Reid and Beyond: Expanding on Modern Native Art, ed. Karen Duffek \& Charlotte Townsend-Gault (Vancouver: Douglas \& MacIntyre, 2004, 251280). For Reid's view of the Raven stories, as the bringer of enlightenment by means of 
transformation, see Bill Reid and Robert Bringhurst, The Raven Steals the Light (Vancouver: Douglas \& MacIntyre, 1984), especially 11-18. For Reid's view of reconciliation with the living earth, after centuries of subduing and plunder, and with Indigenous and non-Indigenous people, see Bill Reid, 'These Shining Islands' \& 'Becoming Haida', The Essential Writings of Bill Reid, Second Edition, ed. Robert Bringhurst (Vancouver: Douglas \& MacIntyre 2009) 222-228 \&229234: 'As for what constitutes a Haida - well, Haida only means human being, and as far as I'm concerned, a human being is anyone who respects the needs of his fellow man, and the earth which nurtures and shelters us all.' (233). See also Haida artist Robert Davidson, who learned to carve under Reid's mentorship, at Sections III.3 and IV.1

${ }^{40}$ Elizabeth Kolbert, The Sixth Extinction: An Unnatural History (New York: Henry Holt, 2014). ${ }^{41}$ Royal Commission on Aboriginal Peoples, Report of the Royal Commission on Aboriginal Peoples, Volume One, Looking Forward, Looking Back (Ottawa: Canadian Communication Group, 1995) 43-244.

42 James Tully, 'Consent, Hegemony, and Dissent in Treaty Negotiations', Jeremy Webber \& Colin M. MacLeod, eds., Between Consenting Peoples: Political Community and the Meaning of Consent (Vancouver: UBC Press, 2010) 233-256, John Borrows, 'Nanabush Goes West: Treaties, and the Trickster in British Columbia', Recovering Canada: The Resurgence of Indigenous Law (Toronto: University of Toronto Press, 2002) 77-110.

${ }^{43}$ It is important to realize that Gandhi criticised the two traditions of reform and violent revolution during Third World decolonization, as both reconciliation-to unsustainable social and ecological relationships, and developed his practices of Satyagraha - nonviolent transformative decolonization and reconciliation-with - in response. See Mahatma Gandhi, Hind Swaraj and other Writings (Cambridge: Cambridge University Press, 1996). See Dennis Dalton, Mahatma Gandhi: Nonviolent Power in Action (New York: Columbia University Press, 2012), Richard Gregg, The Power of Nonviolence (New York: Schocken Books, 1966); and see Taiaiake Alfred, Wasase: Indigenous Pathways of Action and Freedom (Toronto: University of Toronto Press, 2009) 55-58, 204-206 on Gandhian Satyagraha and Indigenous non-violent strategies of decolonization.

44 See Joanna Macy and Chris Johnstone, Active Hope: How to Face the Mess We're in without Going Crazy (Novato CA: New World Library, 2012), Pope Francis, Encyclical on Climate 
Change and Inequality: On Care of Our Common Home (London: Melville House, 2015), Richard Gregg, The Power of Nonviolence (New York: Schocken Books, 1966).

45 James Lovelock, Gaia and the Theory of the Living Planet (London: Gaia Books, 2005), John \& Mary Gribbin, He Knew He Was Right: The Irrepressible Life of James Lovelock (London: Penguin, 2009), and Stephan Harding, Animate Earth: Science, Intuition and Gaia, Second edition (Cambridge MA: Green Books, 2013) for the most relevant introduction to the Gaia theory for our purposes.

${ }^{46}$ Fritjof Capra \& Pier Luigi Luisi, The Systems View of Life (Cambridge: Cambridge University Press, 2014).

${ }^{47}$ Lynn Margulis, Symbiotic Planet (London: Weidenfeld \& Nicholson, 1998), John \& Mary Gribbin, He Knew He Was Right: The Irrepressible Life of James Lovelock (London: Penguin, 2009), 3.

${ }^{48}$ Peter Kropotkin was the first life and social scientist to advance this hypothesis in the modern period in his 1901 classic, Mutual Aid: A Factor of Evolution (Mineola, NY: Dover, 2006 [1901]). It was re-articulated by Barry Commoner, the founder of ecology in the United States, in The Closing Circle: Nature, Man and Technology (New York: Alfred A. Knopf, 1971). . ${ }^{49}$ Stephan Harding, Animate Earth: Science, Intuition and Gaia, Second edition (Cambridge MA: Green Books, 2013) 46-68

${ }^{50}$ Ibid., 68-91

${ }^{51}$ Ibid., 92-112, 190-207

52 Michael Simpson, Ph.D. student in Geography, University of British Columbia, personal correspondence. Compare Alan Rike Drengson \& Duncan MacDonald Taylor, Ecoforestry: The Art and Science of Sustainable Forest Use (Gabriola Island: New Society, 1997), David Suzuki \& Wayne Grady, Tree; A Life Story (Vancouver: Greystone Books, 2004).

${ }^{53}$ Robin Wall Kimmerer, 'Returning the Gift', Minding Nature, 7, 2 (May 2014) 4.

54 Johnny Camille Mack, Thickening Totems and Thinning Imperialism (Faculty of Law, University of Victoria, LLM Dissertation, 2009), Johnny Camille Mack, 'Hoquotisht: Returning to our Canoes Through Stories', Rebecca Johnson, Hester Lessard \& Jeremy Webber, eds., Storied Communities: Narratives of Contact and Arrival (Vancouver: UBC Press, 2010) 00-00. 
${ }^{55}$ Robert Davidson, The Abstract Edge, ed., Karen Duffek ((Vancouver: Museum of Anthropology, 2004) 26. This is his commentary on his artwork entitled 'The World is as Sharp as a Knife'. For the Raven stories on which Davidson draws, see Robert Bringhurst, A Story as Sharp as a Knife: The Classical Haida Mythtellers and Their World (Vancouver: Douglas \& McIntyre, 1999).

${ }^{56}$ Sean Esbjorn-Hargens \& Michael E. Zimmerman, eds., Integral Ecology: Uniting Multiple Perspectives on the Natural World (Boston: Integral Books, 2009).

${ }^{57}$ Fritjof Capra, The Hidden Connections: A Science for Sustainable Living (New York: Anchor Books, 20014) 98-128.

${ }^{58}$ William Rees, 'Thinking Resilience', Richard Heinberg \& Daniel Lerch, eds., The PostCarbon Reader: Managing the $21^{\text {st }}$ Century's Sustainability Crises (Healdsburg, CA. Watershed Media, 2010) 25-42.

${ }^{59}$ Alan Drengson \& Bill Devall, eds., The Ecology of Wisdom: Writings of Arne Naess (Berkeley: Counterpoint, 2008) 99-144, Stephanie Kaza, Mindfully Green XXX

${ }^{60}$ See Joanna Macy and Chris Johnstone, Active Hope: How to Face the Mess We're in without Going Crazy (Novato CA: New World Library, 2012), 43-56, 85-139, Asoka Bandarage, Sustainability and Well-Being: The Middle Path to Environment, Society, and the Economy (London: Palgrave MacMillan, 2013).

${ }^{61}$ Patrick Curry, Ecological Ethics: An Introduction, Second Edition (Cambridge: Polity Press, 2011).

${ }^{62}$ Aldo Leopold, 'The Land ethic', A Sand County Almanac: With Essays on Conservation from Round River (New York: Ballantine Books, 1966) 238-9.

${ }^{63}$ Kim Sterelny, The Evolved Apprentice: How Evolution Made Humans Unique (Cambridge MA: MIT Press, 2012).

${ }^{64}$ Basil Johnston, Ojibway Heritage (Toronto: McLelland \& Stewart, 1987), 41.

${ }^{65}$ Anthony J. Hall, Earth into Property: Colonization, Decolonization, and Capitalism (Montreal \& Kingston: McGill-Queens University Press, 2010).

${ }^{66}$ James Tully, Imperialism and Civic Freedom (Cambridge: Cambridge University Press, 2008) 195-222, 243-267.

${ }^{67}$ Franz Boas, The Mind of Primitive Man (New York: The MacMillan Company 1922 [1911])

2-4. See James Tully, 'Rediscovering the World of Franz Boas: Anthropology, 
Equality/Diversity, and World Peace', Ned Blackhawk \& Isaiah Wilner eds., Indigenous Visions: Rediscovering the World of Franz Boas (New Haven: Yale University Press, 2016, forthcoming). It is significant that Boas came to question Western superiority as the result of extensive discussion with George Hunt and the Kwakwaka'wakaw people of the Northwest coast. See Isaiah Lorado Wilner, 'A Global Potlatch: Identifying the Indigenous Influence on Western Thought', American Indian Culture and Research Journal, 37, 2 (2013) 87-114.

${ }^{68}$ Aldo Leopold, 'The Land ethic', A Sand County Almanac: With Essays on Conservation from Round River (New York: Ballantine Books, 1966) 240: 'In short, a land ethic changes the role of Homo sapiens from conqueror of the land-community to plain member and citizen of it. It implies respect for his fellow-members, and also respect for the community as such.'

${ }^{69}$ Karl Polanyi, Great Transformation: The Political and Economic Origins of Our Time, Foreword by Joseph E. Stiglitz, Introduction by Fred Block (Boston: Beacon Press, 2001 [1944]). I added the first and fourth processes to Polanyi's second and third. I omitted Polanyi's third fictitious commodity, the commodification of money.

${ }^{70}$ John Borrows, 'Sovereignty's Alchemy: An Analysis of Delgamuukw v. British Columbia', (1999) 37 Osgoode Hall Law Journal 537, Joshua Nichols, A Reconciliation without

Recollection: An Investigation of the Foundations of the Indian Act (Faculty of Law, University of Victoria, Ph.D. Dissertation in progress, forthcoming 2017), Kent McNeill, this volume.

${ }^{71}$ Royal Commission on Aboriginal Peoples, Report of the Royal Commission on Aboriginal Peoples, Volume One, Looking Forward, Looking Back (Ottawa: Canadian Communication Group, 1995). See John Borrows, 'Domesticating Doctrines: Aboriginal Peoples after the Royal Commission', McGill Law Journal, 46 (2001) 615-661.

${ }^{72}$ See Sections I.1, I.4, references at notes 3, 29, 30, and Stephan Harding, Animate Earth: Science, Intuition and Gaia, Second edition (Cambridge MA: Green Books, 2013) 208-249. ${ }^{73}$ Naomi Klein, This Changes Everything: Capitalism versus the Climate (New York: Simon \& Schuster, 2014), Irene Khan, The Unheard Truth: Poverty and Human Rights (New York: W.W. Norton \& Company, 2009).

${ }^{74}$ For this transformation to representative democracy in the nineteenth-century, see Francis Dupuis-Déri, Démocratie: Histoire Politique d'un mot (Montréal: Lux Ẽditeur, 2013). For the globalization of this module, see James Tully, Imperialism and Civic Freedom (Cambridge: Cambridge University Press, 2008) 243-267. 
${ }^{75}$ Karl Polanyi, Great Transformation: The Political and Economic Origins of Our Time, (Boston: Beacon Press, 2001 [1944]) 181: 'To allow the market mechanism to be sole director of the fate of human beings and their natural environment...would result in the demolition of society. Robbed of the protective covering of cultural institutions, human beings would perish from the effects of social exposure; they would die as the victims of acute social dislocation through vice, perversion, crime and starvation. Nature would be reduced to its elements, neighbourhoods and landscapes defiled, rivers polluted, military safety jeopardized, the power to produce food and raw materials destroyed'

${ }^{76}$ See Craig Dilworth, Too Smart for Our Own Good: The Ecological Predicament of Humankind (Cambridge: Cambridge University Press, 2010), Fritjof Capra, The Hidden Connections: A Science for Sustainable Living (New York: Anchor Books, 20014) 129-157.

${ }^{77}$ Michael Klare, The Race for What's Left: The Global Scramble for the World's Last Resources (New York: Picador, 2012, Lester R. Brown, World on the Edge: How to Prevent Environmental and Economic Collapse (New York: W.W. Norton, 2011).

${ }^{78}$ Compare: Robert Nichols, 'Disaggregating Primitive Accumulation: The Dialectic of Labor and Land', Radical Philosophy, 194 (Nov-Dec 2015) 18-28, Kamran Nayeri, 'Capitalism in the Web of Life' - A Critique', Climate and Capitalism, July 19, 2016, 1-20, 8-13, at http://climateandcapitalism.com/2016/07/19/capitalism-in-the-web-of-life-a-critque/. I am indebted to conversations with Robert Nichols on how best to characterise this first process of 'dispossession'.

${ }^{79}$ Paul Hawken, Blessed Unrest: How the Largest Movement in the World Came into Being and Why No One Saw it Coming (New York: Viking, 2007), Boaventura de Sousa Santos, Epistemologies of the South: Justice against Epistemicide (Boulder: Paradigm Publishers, 2014). Hawken argues that Indigenous people are the leading edge of these social networks.

${ }^{80}$ Asoka Bandarage, Sustainability and Well-Being: The Middle Path to Environment, Society, and the Economy (London: Palgrave MacMillan, 2013).

${ }^{81}$ John Borrows, 'The Durability of Terra Nullius: Tsilhqot'in Nation v British Columbia', (2015) 48:3 UBC L. Rev. 701, and see note 67.

${ }^{82}$ William McDonough \& Michael Braungart, Cradle to Cradle: Remaking the Way We Make Things (New York: North Point Press, 2002). 
${ }^{83}$ This was the finding of the first Limits to Growth model in 1972 (Donella H. Meadows, Dennis L. Meadows, et al., The Limits to Growth: A Report for the Club of Rome's Project on the Predicament of Mankind (New York: Universe Books, 1971)). It was defended and updated in 2012 (Ugo Bardi, The Limits to Growth Revisited (New York, Springer, 2012)). Lester Brown refers to this as the 'fatal flaw' of the global economy (Lester R. Brown, World on the Edge: How to Prevent Environmental and Economic Collapse (New York: W.W. Norton, 2011) 15) 8. 84 This is the first feature of a crisis of reconciliation in Section I.4.

85 This is the 'independent' mode of self-perception at Section I.3. For the first analysis of the ecological crisis as this kind of perceptual/praxis misrepresentation, see Barry Commoner, The Closing Circle: Nature, Man and Technology (New York: Alfred A. Knopf, 1971) 14. For a striking example of the disastrous effects of this misperception in settlement patterns, see Nancy Turner and Pamela Spaulding, this volume.

${ }^{86}$ Robert Davidson, The Abstract Edge, ed., Karen Duffek ((Vancouver: Museum of Anthropology, 2004) 36. This is his commentary on his artwork entitled 'Ravenous'. ${ }^{87}$ Claude Lévi-Strauss in conversation with Wilson Duff in 1974, cited in Wayne Suttles, 'The World is as Sharp as a Knife: A Review Article [of Donald N. Abbott, ed., The World is as Sharp as a Knife: An Anthology in Honour of Wilson Duff (Victoria: Provincial Museum, 1981)], BC Studies, 56 (Winter 1982-1983) 82-91, 90.

${ }^{88}$ See Kim Sterelny, The Evolved Apprentice: How Evolution Made Humans Unique (Cambridge MA: MIT Press, 2012), David Abram, Becoming Animal: An Earthly Cosmology (New York: Vintage Books, 2010.

${ }^{89}$ Aldo Leopold, 'The Land ethic', A Sand County Almanac: With Essays on Conservation from Round River (New York: Ballantine Books, 1966) 137-141.

${ }^{90}$ For an introduction to the ways of 'transformative reconnection' with the living earth and with indigenous peoples, see Joanna Macy and Chris Johnstone, Active Hope: How to Face the Mess We're in without Going Crazy (Novato CA: New World Library, 2012) 13-84, Paul Hawken, Blessed Unrest: How the Largest Movement in the World Came into Being and Why No One Saw it Coming (New York: Viking, 2007), Stephan Harding, Animate Earth: Science, Intuition and Gaia, Second edition (Cambridge MA: Green Books, 2013) 36-67.

91 Robert Davidson, 'Untitled Document', included in the catalogue for 'Robert Davidson Exhibition: A Voice from Inside' (Vancouver: Derek Simpson Gallery, 1992) 1-3, 3, available at 
www.robertdavidson.ca/writings/edge_of_a knife. For the whole movement of transformative reconnection on Haida Gwaii to which Davidson refers see Louise Takeda, Islands' Spirit Rising: Reclaiming the Forests of Haida Gwaii (Vancouver: UBC Press, 2015).

92 See Isaiah Lorado Wilner, Raven Cried for Me: Narratives of Transformation on the Northwest Coast of America (New Haven: Yale University Ph.D. Dissertation 2016), Alan Hoover, 'Charles Edenshaw and the Development of Narrative Structure in Nineteenth-century Haida Art', Robin K. Wright \& Daina Augaitis, eds., Charles Edenshaw (London: Black Dog Publishing, 2015) 67-73.

93 See references at note 41, Thich Nhat Hanh, Love Letter to the Earth (Berkeley: Parallax Press, 2014), Stephanie Kaza, Mindfully Green: A Personal and Spiritual Guide to Whole Earth Thinking (Boston: Shambhala, 2008).

94 This internal relationship between being, disclosing and knowing is now called the Santiago theory of cognition, but, as we have seen, it is as old as traditional Indigenous knowledge and stories. For the Santiago theory, see Fritjof Capra \& Pier Luigi Luisi, The Systems View of Life (Cambridge: Cambridge University Press, 2014) 255-257, 262.

95 This is the revolution in education called for by Fritjof Capra in Section I.2 and explained in the life and human sciences in Section II, sometimes referred to as biomimicry and holistic science. For an introduction, see references at note 10 and Stephan Harding, Animate Earth: Science, Intuition and Gaia, Second edition (Cambridge MA: Green Books, 2013) 35-45, ${ }^{96}$ See, for example, Zoltan Grossman \& Alan Parker, eds., Asserting Native Resilience: Pacific

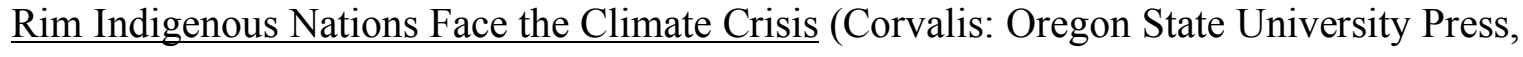
2012). For a leading example in the area of law, see the programs in the Faculty of Law at the University of Victoria for the teaching of Indigenous and Common law: www.uvic/law/ilrc.

97 This is the central theme of Vandana Shiva, Earth Democracy: Justice, Sustainability and Peace (Cambridge MA: South End Press, 2005).

${ }^{98}$ See Section III.3. For a recent survey of the field, see Greg Poeltzer \& Ken S. Coates, From Treaty Peoples to Treaty Nation: A Road Map for all Canadians (Vancouver: UBC Press, 2015). ${ }^{99}$ Valerie Napoleon and Hadley Friedland are law professors at the University of Victoria. The teaching method they have developed in used in the classroom and in Indigenous communities throughout British Columbia. It is called the 'TullyWheel' because they draw creatively on the 
types of engaged and landed citizen practices I discuss in James Tully, Public Philosophy in a New Key, Volume II, (Cambridge: Cambridge University Press 2008) 243-311. See Val Napoleon and Hadley Friedland, 'Accessing Tully: Political Philosophy for the Everyday and the Everyone', Robert Nichols \& Jakeet Singh, eds., Freedom and Democracy in an Imperial Context: Dialogues with James Tully (London: Routledge 2014) 202-222).

${ }^{100}$ These four types of transformative practices of reconciliation-with are similar to the four main types of practices of Gandhi's Satyagraha: his way of transforming oppressive relationships and reconciling the partners. See references at notes 33, 34 and 40 to convergence among several Indigenous and non-Indigenous scholars on the centrality of these four types of gift-reciprocity practices in response to the dual crisis.

101 The list of examples in this paragraph is drawn from the literature referred to in the notes to this chapter. For 'cyclical' or ecological economics, see Peter G. Brown \& Peter Timmerman, eds., Ecological Economics for the Anthropocene (New York: Columbia University Press, 2015). For a survey of research on sustainable systems, see Gar Alperovitz, James Gustave Speth \& Joe Guinan, The Next System Project: New Political-Economic Possibilities for the $21^{\text {st }}$ Century, (2016), at www.thenextsystem.org. The world of transformative practice is outgrowing by far the academic research and surveys of it. I discuss some examples and respond to criticisms of them in James Tully, On Global Citizenship: James Tully in Dialogue (London: Bloomsbury, 2014) and Robert Nichols \& Jakeet Singh, eds., Freedom and Democracy in an Imperial Context: Dialogues with James Tully (London: Routledge 2014), but this is barely the tip of the regenerative world of conciliatory and sustainable practices and networks.

${ }^{102}$ For example, Taiaiake 'Resurgence and Reconciliation', Dimitrios Karmis \& Jocelyn Maclure eds., Diversity and Civic Freedom (Montreal: forthcoming 2017). ${ }^{103}$ The Two Row Wampum treaty relationship (Tekani Teioha:te) manifests both selfgovernment and shared-government.

104 For the Indigenous and non-Indigenous partnerships on Haida Gwaii, see Louise Takeda, Islands' Spirit Rising: Reclaiming the Forests of Haida Gwaii (Vancouver: UBC Press, 2015).

105 See, for example, Sarah Marie Wiebe, Everyday Exposure: Indigenous Mobilization and Environmental Justice in Canada's Chemical Valley (Vancouver: UBC Press, 2016). ${ }^{106}$ See Section I.2 and Michael Asch, On Being Here to Stay: Treaties and Aboriginal Rights in Canada (Toronto: University of Toronto Press, 2014), Michael Asch, this volume. 
${ }^{107}$ See John Borrows, Canada's Indigenous Constitution (Toronto: University of Toronto Press, 2010), John Borrows, this volume, Aaron Mills, this volume.

${ }^{108}$ See Sections I.4 \& II. 